Review

\title{
Serum Vitamin D as a Biomarker in Autoimmune, Psychiatric and Neurodegenerative Diseases
}

\author{
Giulia Bivona ${ }^{1,+}$ () , Caterina Maria Gambino ${ }^{1,+}{ }^{\dagger}$, Bruna Lo Sasso ${ }^{1}$, Concetta Scazzone ${ }^{1}$, Rosaria Vincenza Giglio ${ }^{1}$, \\ Luisa Agnello ${ }^{1}$ and Marcello Ciaccio ${ }^{1,2, *(\mathbb{D})}$
}

1 Department of Biomedicine, Neurosciences and Advanced Diagnostics, Institute of Clinical Biochemistry, Clinical Molecular Medicine and Clinical Laboratory Medicine, University of Palermo, 90127 Palermo, Italy; giulia.bivona@unipa.it (G.B.); cmgambino@libero.it (C.M.G.); bruna.losasso@unipa.it (B.L.S.); concetta.scazzone@unipa.it (C.S.); giglio.rosaria.vincenza@gmail.com (R.V.G.); luisa.agnello@unipa.it (L.A.)

2 Department of Laboratory Medicine, University Hospital "P. Giaccone", 90127 Palermo, Italy

* Correspondence: marcello.ciaccio@unipa.it; Tel.: +39-0916553296

+ These authors contributed equally to this work.

check for

updates

Citation: Bivona, G.; Gambino, C.M.; Lo Sasso, B.; Scazzone, C.; Giglio, R.V.; Agnello, L.; Ciaccio, M. Serum Vitamin D as a Biomarker in Autoimmune, Psychiatric and Neurodegenerative Diseases. Diagnostics 2022, 12, 130. https:/ / doi.org/10.3390/diagnostics12010130

Academic Editor: Benedetta Nacmias

Received: 13 December 2021

Accepted: 5 January 2022

Published: 6 January 2022

Publisher's Note: MDPI stays neutral with regard to jurisdictional claims in published maps and institutional affiliations.

Copyright: (c) 2022 by the authors. Licensee MDPI, Basel, Switzerland. This article is an open access article distributed under the terms and conditions of the Creative Commons Attribution (CC BY) license (https:// creativecommons.org/licenses/by/ $4.0 /)$.

\begin{abstract}
Vitamin D is a steroid hormone regulating calcium-phosphorus homeostasis, immune response and brain function. In the past thirty years, an increasing number of cohort studies, metaanalyses and randomized controlled trials (RTCs) evaluated the serum levels of 25-hydroxyvitamin D [25(OH)D], which is considered the Vitamin D status biomarker, in patients affected by neurological, psychiatric and autoimmune diseases. Although an association between low 25(OH)D serum levels and the prevalence of these diseases has been found, it is still unclear whether the serum $25(\mathrm{OH}) \mathrm{D}$ measurement can be clinically useful as a biomarker for diagnosis, prognosis and predicting treatment response in neurodegeneration, mental illness and immune-mediated disorders. The lack of standardized data, as well as discrepancies among the studies (in the analytical methods, cut-offs, endpoints and study sets), weakened the findings achieved, hindered pooling data, and, consequently, hampered drawing conclusions. This narrative review summarizes the main findings from the studies performed on serum $25(\mathrm{OH}) \mathrm{D}$ in neurological, psychiatric and autoimmune diseases, and clarifies whether or not serum 25(OH)D can be used as a reliable biomarker in these diseases.
\end{abstract}

Keywords: vitamin D; biomarker; autoimmune diseases; neurodegenerative diseases; psychiatric diseases; Alzheimer's disease; multiple sclerosis; standardization; 25(OH)D

\section{Introduction}

Vitamin D is an endogenous compound belonging to the steroid hormones class.

Humans synthesize active Vitamin D starting from a precursor on the skin, although a small amount can also be taken by diet.

Vitamin D became known in the early 1900s, and its metabolism was broadly revised when it was found in a wide range of organs, tissues and cytotypes producing the hormone and receiving its signal. It was born in the era of the so-called Vitamin D "non-skeletal activities", with an increasing number of studies uncovering some roles of the hormone, counting the regulation of brain function and immune response [1]. In addition, the autocrine and paracrine fashion in which Vitamin D behaves in these organs and tissues became apparent. Since Vitamin D has been regarded as a neurosteroid and immunomodulator, the $25(\mathrm{OH}) \mathrm{D}$ circulating levels in patients affected by neurological, psychiatric and autoimmune diseases have been evaluated [2-6]. The rationale to search for a role of Vitamin D in these diseases was that the hormone can influence and modify various cerebral processes, including the effectiveness of connectivity in some neural circuits involved in cognition, memories and emotional behavior. Additionally, it can modulate many immunological events of both innate and adaptive arms of immunity, ranging from neutrophils and macrophages' antimicrobial activity to T helper lymphocytes cytokine production. Consistently, Vitamin 
D circulating levels have been extensively measured in patients affected by autoimmune diseases, revealing, for instance, a large spectrum of Vitamin D receptor (VDR) polymorphisms in the frequency and severity of some pathologies, and a high prevalence of low Vitamin D concentrations among these patients. Additionally, a broad number of authors have focused their research on the impact of low Vitamin D levels on some features of neurodegenerative diseases, specifically Alzheimer's disease (AD) and Parkinson's disease (PD), uncovering a possible role of the hormone as a biomarker for predicting disease severity in these patients.

Collectively, in the past three decades, a wide amount of studies have been per-formed on the 25-hydroxyvitamin D [25(OH)D] levels in patients having neurological, psychiatric and autoimmune diseases, but these studies were quite different in terms of patients, design, methods, assay technologies, and displaying diverse strengths and flaws. On the one hand, this could explain the failure to reach univocal conclusions on a possible role of serum $25(\mathrm{OH}) \mathrm{D}$ as a biomarker for the hormone in such diseases, and, on the other hand, this represents a rationale to review the literature on this topic, in order to synthesize and critically analyze the main findings and conclusions from the studies.

This narrative review summarizes the main findings from the studies performed on Vitamin D serum levels in patients affected by the autoimmune, neurological and psychiatric diseases, and clarifies whether $25(\mathrm{OH}) \mathrm{D}$ measurement in these patients impacts their clinical management, influencing diagnosis, prognosis and treatment of these patients.

\section{Vitamin D Metabolism}

The Vitamin D active form is produced in a multi-step process, including the ultraviolet B (UVB) rays' irradiation of a cutaneous precursor [7-dehydro-cholesterol (7-DHC)], and two hydroxylation steps. In addition to the synthesis of Vitamin D, 7-DHC can be oriented toward the production of cholesterol by the 7-DHC reductase (7-DHCR) enzyme, within the Kandutsch-Russell biochemical pathway, that occurs in the skin, brain, muscle and heart (Figure 1) [1]. Since 7-DHCR regulates the amount of DHC available for Vitamin D conversion, this enzyme represents the first limiting step for Vitamin D synthesis.

UVB irradiation of 7-DHC forms the cholecalciferol, which undergoes first hydroxylation in the liver by a 25 hydroxylase (CYP2R1, CYP3A4 and CYP27A1), generating $25(\mathrm{OH}) \mathrm{D}$, and the second in the kidney by renal 1,25 hydroxylase (CYP27B1), producing 1,25 , dihydroxyvitamin $\mathrm{D}[1,25(\mathrm{OH}) 2 \mathrm{D}]$. The latter is released in blood to reach the bowel, where it regulates calcium absorption. However, 1,25 hydroxylase is present within various organs and cells, including the lung, brain, prostate, placenta and immune system cells, where the active Vitamin D can be synthesized to regulate some cellular processes, including cell differentiation and proliferation [7]. Renal CYP27B1 is up-regulated by the parathyroid hormone (PTH) and down-regulated by the fibroblast growth factor (FGF23) and 1,25(OH)2D, whereas extra-renal CYP27B1 is regulated by interferon $\gamma(\mathrm{IFN}-\gamma)$ and tumor necrosis factor (TNF) [7,8].

Vitamin D binding protein (VDBP) transports both 25(OH)D and 1,25(OH)2D from the liver and kidney to other tissues, where they are taken up throughout the plasma membrane by HSP70 [1,9]. VDBP is a high-polymorphic gene, and, as a consequence, there is wide variability in the protein function. As a result, the individual's response to Vitamin D supplementation varies according to the VDBP variants, influencing the amount of circulating exogenous protein-bound Vitamin D (see Section 5) [9]. Within the megalin cubilin complex- non-expressing cells, 25(OH)D reaches mitochondria by HSP70, where it is converted in $1,25(\mathrm{OH}) 2 \mathrm{D}$. Then, it can be transported to the nucleus, where it binds the Vitamin D receptor (VDR) [10], leading to the genomic and non-genomic actions (for more details on Vitamin D genomic and non-genomic actions see refs [11,12]). Cellspecific factors, including transcription factors, can influence how a citotype responds to the VDR/ligand binding. Thus, different tissues display distinct feedbacks to the hormone since the CYP27B1 promoter region responds to different stimuli based on the cell types $[1,13]$. For instance, 1,25(OH)2D inhibits CYP27B1 in the renal cells, but not in macrophages. 
Vitamin D catabolism is carried out by a 24 hydroxylase enzyme (CYP24A1).

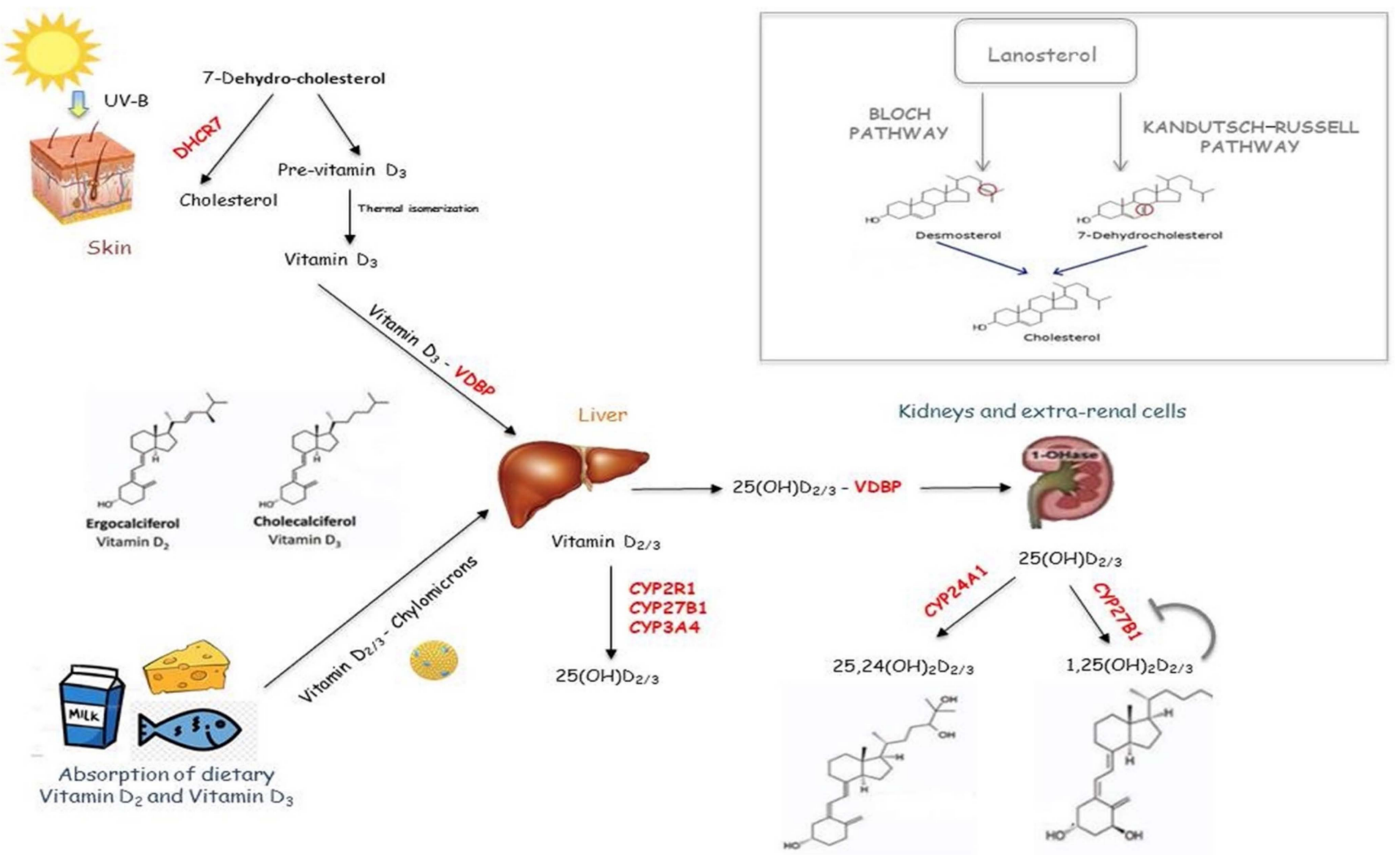

Figure 1. Vitamin D metabolism pathway. Vitamin D active form is produced in a multi-step process, including the ultraviolet B (UVB) rays' irradiation of a cutaneous precursor [7-dehydro-cholesterol (7-DHC)], and two hydroxylation steps. In addition to the synthesis of Vitamin D, 7-DHC can be oriented toward the production of cholesterol by Kandutsch-Russell biochemical pathway.

Vitamin D exerts pleiotropic effects. The most known function of Vitamin D is the regulation of calcium homeostasis. However, over the course of the last decades, it has become increasingly clear that the effects of Vitamin D are not limited to the maintenance of calcium homeostasis. Indeed, it regulates multiple cellular processes, including cell growth and differentiation, and influences the functions of cells of the immune, nervous and cardiovascular systems as well as muscles and the pancreas (Figure 2). The role of Vitamin $\mathrm{D}$ in inflammation has gained attention. First of all, immune cells produce 1,25(OH)2D and express the VDR and the enzymes for metabolizing Vitamin D3. The Vitamin D3 synthesized within CNS exerts both autocrine and paracrine immunomodulating effects on innate and adaptive immune responses. Specifically, it promotes the anti-inflammatory phenotype by regulating T cells, B cells and antigen-presenting cells (dendritic cells and macrophages) (Figure 2). 


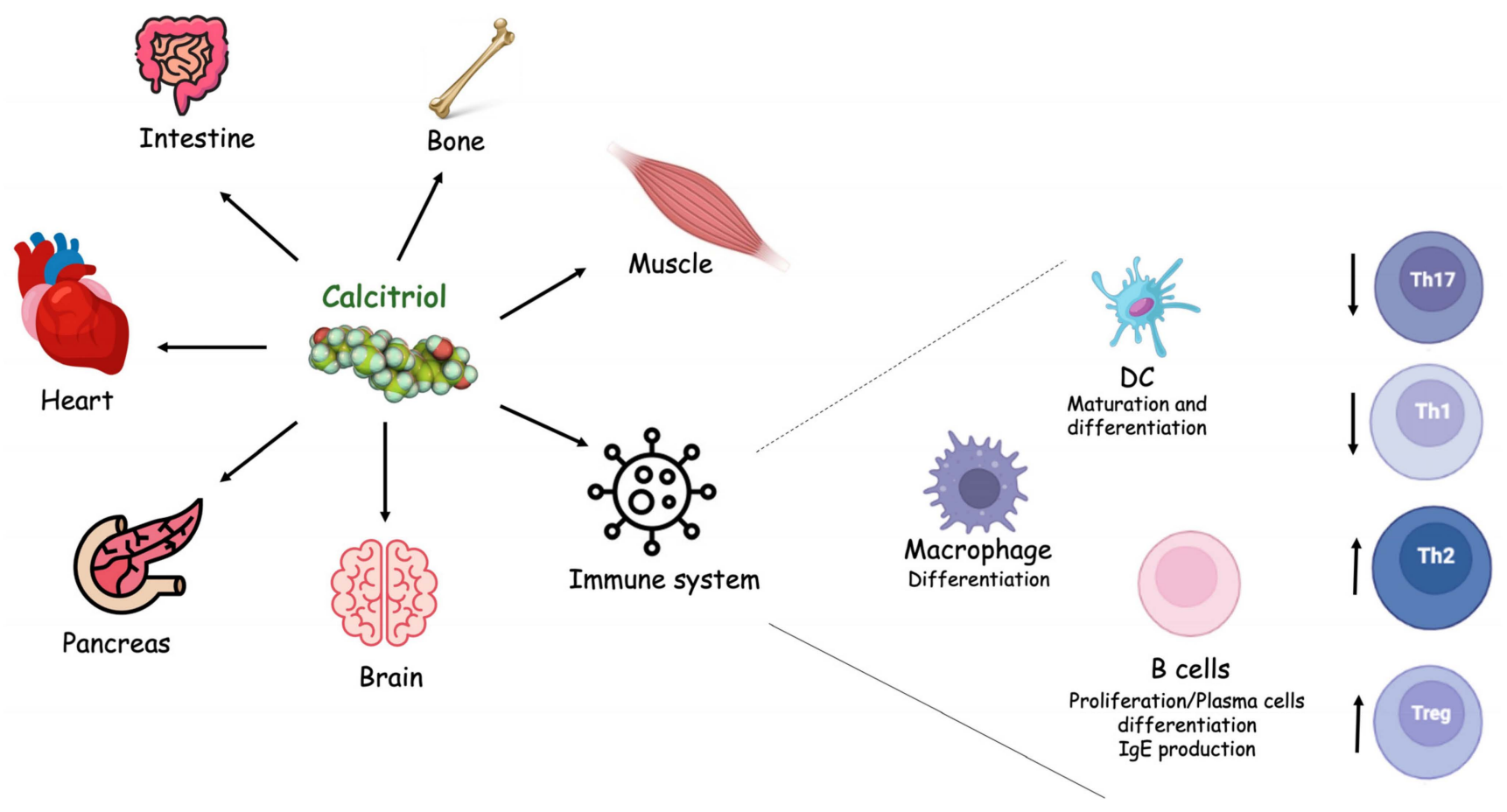

Figure 2. Vitamin D biological functions. Vitamin D's active form, also known as calcitriol, exerts pleiotropic functions on different cells and organs.

\section{Vitamin D Status Assessment and 25(OH)D Measurement Standardization}

Vitamin D status is typically evaluated by measuring serum 25(OH)D [14], but it should be highlighted that serum $25(\mathrm{OH}) \mathrm{D}$ measurement for many decades has been affected by a lack of standardization.

Standardization means aligning laboratories and assays with the "true" concentration, based on internationally recognized reference procedures and materials, regardless of the place, time and assay systems [15]. To address the problem of $25(\mathrm{OH}) \mathrm{D}$ measuring standardization, the Vitamin D Standardization Program (VDSP) has been created, leading researchers working worldwide to collaborate with well-established health institutions (including the International Federation of Clinical Chemistry and Laboratory MedicineIFCC, the Ghent University, the Vitamin D External Quality Assessment Scheme-DEQAS, and the National Institute for Standard and Technology-NIST). The specific purpose of VDSP is to encourage laboratories and manufacturers to reduce the analytical variability of the 25(OH)D measurement with national health and nutrition surveys [16]. The VDSP protocols for standardization of serum $25(\mathrm{OH}) \mathrm{D}$ have been applied to national surveys in Europe, Canada and the USA [17-19].

Within the VDSP, the DEQAS aims specifically to assess the accuracy of the results produced by participants. The NIST has developed a liquid chromatography-tandem mass spectrometry (LC/MS-MS) assay, which has been accepted by the Joint Committee for Traceability in Laboratory Medicine (JCTLM) as the reference measurement procedure (RMP) for 25(OH)D [20]. The accuracy of the results is assessed by comparing them to the NIST value, being that the NIST value is recognized as the target value [21,22]. The accuracy of a result is calculated as the percentage of bias of the result from the target (or "true") value provided by NIST [22]. 
VDSP collaboration is based on the encouragement to use methods and materials traceable to the NIST reference measurement procedures (RMPs) and standard reference materials (SRMs) [16,21-24].

As for many other molecules, the lack of standardization in the past decades hindered reaching a consensus on which $25(\mathrm{OH}) \mathrm{D}$ levels define Vitamin D sufficiency, deficiency and insufficiency [25-27]. Optimal Vitamin D status is regarded as the $25(\mathrm{OH}) \mathrm{D}$ levels required to maintain skeletal health, whereby $25(\mathrm{OH}) \mathrm{D}$ values below $30 \mathrm{~nm} / \mathrm{L}$ are considered to be associated with an increased risk of rickets/osteomalacia, while values between 30 and $50 \mathrm{~nm} / \mathrm{L}$ are considered to be sufficient for skeletal health [15].

\section{Vitamin D as a Disease Marker}

Generally, a biomarker is regarded as a molecule that is used to identify, monitor and predict treatment responses to a certain disease or condition. Specifically, a biomarker is measured to diagnose a disease and to predict its severity, having, consequently, a strong impact on clinical management as per the ward to be oriented and therapy to be administered. Probably, the most requested feature of a biomarker is predicting treatment response, with several known examples on this topic, including procalcitonin for guiding therapy in sepsis. It is widely accepted that the construct of the "clinical usefulness" of a biomarker fully depends on the above-mentioned characteristics. However, it should be noted that a correlation between the marker and some disease features, including severity, does not always mean the biomarker is useful in the clinical practice, because many molecules can change among different disease stages independently of the pathophysiological link between biomarker levels variation and disease features. In other words, before any biomarker enters clinical practice, an influence on treatment administration and response, as well as disease course and patient condition should be proven. Regarding the possible role of Vitamin D as a biomarker in neurological, psychiatric and autoimmune diseases, a correlation between the hormone concentrations and some disease characteristics has been proven. However, it is not clear whether measuring $25(\mathrm{OH}) \mathrm{D}$ can modify clinical management and disease course in these patients.

\subsection{Autoimmune Diseases}

Among all autoimmune diseases, 25(OH)D serum levels have been mostly investigated in systemic lupus erythematosus (SLE), systemic sclerosis (SS), rheumatoid arthritis (RA), autoimmune thyroid diseases and multiple sclerosis (MS) (Table 1). 
Table 1. Major findings from the observational studies evaluating Vitamin D serum levels in autoimmune diseases.

\begin{tabular}{|c|c|c|c|c|c|c|c|}
\hline Disease & Authors & Ref & $\begin{array}{l}\text { Publication } \\
\text { Time }\end{array}$ & Sample Size & $\begin{array}{l}\text { Cut-Off Value for } \\
\text { Vitamin D }\end{array}$ & $\begin{array}{c}\text { Ethnic/Cultural/Geographical } \\
\text { Features }\end{array}$ & Findings \\
\hline \multicolumn{8}{|l|}{ SLE } \\
\hline & Petri et al. & [28] & 2013 & 1006 & $40 \mathrm{ng} / \mathrm{mL}$ & $\begin{array}{c}\text { Caucasian }(54 \%), \\
\text { African-American }(37 \%), \\
\text { other }(8 \%)\end{array}$ & $\begin{array}{c}25(\mathrm{OH}) \mathrm{D} \text { levels of } 40 \mathrm{ng} / \mathrm{mL} \text { or above are } \\
\text { not associated with improvement in } \\
\text { disease activity }\end{array}$ \\
\hline & AlSaleem et al. & [29] & 2015 & 28 & $\begin{array}{l}\text { Normal } \geq 30-100 \mathrm{ng} / \mathrm{mL}, \\
\text { Insufficient } 21-29 \mathrm{ng} / \mathrm{mL}, \\
\text { Deficient }<20 \mathrm{ng} / \mathrm{mL}\end{array}$ & Saudi & $\begin{array}{l}\text { High daily Vitamin D3 supplementation } \\
\text { could impact disease activity }\end{array}$ \\
\hline & Eloi et al. & [30] & 2017 & 199 & $\begin{array}{l}\text { Insufficient } 10-30 \mathrm{ng} / \mathrm{mL}, \\
\text { Deficient }<10 \mathrm{ng} / \mathrm{mL}\end{array}$ & Brazilian & $\begin{array}{l}\text { Disease activity is associated with lower } \\
\text { serum concentrations of } 25(\mathrm{OH}) \mathrm{D}\end{array}$ \\
\hline & Salman-Monte et al. & {$[31]$} & 2016 & 102 & NA & Spanish & $\begin{array}{l}\text { Vitamin D insufficiency is highly prevalent } \\
\text { among female SLE patients, even in } \\
\text { southern regions }\end{array}$ \\
\hline & Andreoli et al. & [32] & 2012 & 115 & $\begin{array}{l}\text { Insufficient } 10-30 \mathrm{ng} / \mathrm{mL} \\
\text { Deficient }<10 \mathrm{ng} / \mathrm{mL}\end{array}$ & Italian & $\begin{array}{c}\text { Patients with antiphospholipid syndrome } \\
\text { have low } 25(\mathrm{OH}) \text { D levels }\end{array}$ \\
\hline & Aranow et al. & [33] & 2015 & 125 & $20 \mathrm{ng} / \mathrm{mL}$ & NA & $\begin{array}{l}\text { Vitamin D3 supplementation does not } \\
\text { diminish the expression of IFN } \alpha \\
\text { inducible genes }\end{array}$ \\
\hline & Dall'Ara et al. & [34] & 2018 & NA & NA & NA & $\begin{array}{l}\text { Vitamin D insufficiency is endemic in } \\
\text { SLE patients }\end{array}$ \\
\hline \multicolumn{8}{|l|}{ SSc } \\
\hline & Lin et al. & [35] & 2017 & 554 & $\begin{array}{l}\text { Insufficient } 10-30 \mathrm{ng} / \mathrm{mL}, \\
\text { Deficient }<10 \mathrm{ng} / \mathrm{mL}\end{array}$ & NA & $\begin{array}{c}\text { SSc patients exhibit low Vitamin D levels. } \\
\text { The severity of clinical features is not } \\
\text { associated with the extent of } \\
\text { Vitamin D deficit }\end{array}$ \\
\hline & Gupta et al. & [36] & 2018 & 38 & $\begin{array}{l}\text { Normal } 30-100 \mathrm{ng} / \mathrm{mL} \\
\text { Insufficient } 10-30 \mathrm{ng} / \mathrm{mL}, \\
\text { Deficient }<10 \mathrm{ng} / \mathrm{mL}\end{array}$ & NA & $\begin{array}{c}\text { Geographic origin or clinical presentation } \\
\text { of SSc patients does not influence } \\
25(\mathrm{OH}) \mathrm{D} \text { levels }\end{array}$ \\
\hline
\end{tabular}


Table 1. Cont.

\begin{tabular}{|c|c|c|c|c|c|c|c|}
\hline Disease & Authors & Ref & $\begin{array}{l}\text { Publication } \\
\text { Time }\end{array}$ & Sample Size & $\begin{array}{l}\text { Cut-Off Value for } \\
\text { Vitamin D }\end{array}$ & $\begin{array}{c}\text { Ethnic/Cultural/Geographical } \\
\text { Features }\end{array}$ & Findings \\
\hline \multicolumn{8}{|l|}{ RA } \\
\hline & Polasik et al. & [37] & 2017 & 35 & $20 \mathrm{ng} / \mathrm{mL}$ & Polish & $\begin{array}{l}25(\mathrm{OH}) \mathrm{D} \text { levels were similar in RA patients } \\
\text { and age- and gender-matched healthy } \\
\text { controls and were not associated with joint } \\
\text { damage and disease activity in patients }\end{array}$ \\
\hline & Wong et al. & {$[38]$} & 2017 & 77 & $20 \mathrm{ng} / \mathrm{mL}$ & Malaysian & $\begin{array}{c}\text { Mean 25(OH)D levels in RA patients were } \\
\text { low, but similar to the age-matched } \\
\text { healthy controls }\end{array}$ \\
\hline & Kerr et al. & [39] & 2011 & 850 & $\begin{array}{l}\text { Insufficient }<30 \mathrm{ng} / \mathrm{mL} \\
\text { Deficient }<20 \mathrm{ng} / \mathrm{mL}\end{array}$ & Caucasian males & $\begin{array}{l}25-\mathrm{OH}-\mathrm{D} \text { insufficiency is associated with } \\
\text { disease severity, not clinical disease activity }\end{array}$ \\
\hline & Pakchotanon et al. & {$[40]$} & 2016 & 239 & $\begin{array}{c}\text { Normal }>30 \mathrm{ng} / \mathrm{mL} \\
\text { Insufficient } 10-30 \mathrm{ng} / \mathrm{mL}, \\
\text { Deficient }<10 \mathrm{ng} / \mathrm{mL}\end{array}$ & Thai & $\begin{array}{c}\text { No associations between serum } 25(\mathrm{OH}) \mathrm{D} \\
\text { levels and disease activity or } \\
\text { functional status }\end{array}$ \\
\hline & Gopal et al. & [41] & 2019 & 100 & $50 \mathrm{nmol} / \mathrm{L}$ & Malaysian & $\begin{array}{l}25(\mathrm{OH}) \mathrm{D} \text { is not associated with disease } \\
\text { activity or serum IL- } 6 \text { levels but it may } \\
\text { have a role in functional disability }\end{array}$ \\
\hline & Lin et al. & [42] & 2016 & 3489 & NA & NA & $\begin{array}{c}\text { Serum Vitamin D levels are lower in RA } \\
\text { patients and are inversely associated with } \\
\text { disease activity }\end{array}$ \\
\hline \multicolumn{8}{|c|}{ Autoimmune Thyroiditis } \\
\hline & Wang et al. & [43] & 2015 & 1782 & $20 \mathrm{ng} / \mathrm{mL}$ & NA & $\begin{array}{c}\text { Low levels of serum } 25(\mathrm{OH}) \mathrm{D} \text { are related to } \\
\text { autoimmune thyroiditis }\end{array}$ \\
\hline & Muscogiuri et al. & [44] & 2016 & 50 & $50 \mathrm{nmol} / \mathrm{L}$ & Italian & $\begin{array}{l}\text { Low levels of } 25(\mathrm{OH}) \mathrm{D} \text { were significantly } \\
\text { associated with } \\
\text { autoimmune thyroiditis in women with } \\
\text { polycystic ovary syndrome }\end{array}$ \\
\hline
\end{tabular}


Table 1. Cont.

\begin{tabular}{|c|c|c|c|c|c|c|c|}
\hline Disease & Authors & Ref & $\begin{array}{l}\text { Publication } \\
\text { Time }\end{array}$ & Sample Size & $\begin{array}{l}\text { Cut-Off Value for } \\
\text { Vitamin D }\end{array}$ & $\begin{array}{c}\text { Ethnic/Cultural/Geographical } \\
\text { Features }\end{array}$ & Findings \\
\hline \multicolumn{8}{|c|}{ Autoimmune Thyroiditis } \\
\hline & Muscogiuri et al. & [45] & 2016 & 168 & $\begin{array}{l}\text { Normal } \geq 20 \mathrm{ng} / \mathrm{mL} \\
\text { Deficient } \leq 20 \mathrm{ng} / \mathrm{mL}\end{array}$ & Italian & $\begin{array}{l}\text { Vitamin D deficiency was significantly } \\
\text { associated with autoimmune thyroiditis in } \\
\text { the elderly }\end{array}$ \\
\hline & D'Aurizio et al. & [46] & 2015 & NA & NA & NA & $\begin{array}{l}\text { Conflicting results have been obtained } \\
\text { about the association between Vitamin D } \\
\text { and autoimmune thyroiditis }\end{array}$ \\
\hline & Effraimidis et al. & [47] & 2012 & 78 & $\begin{array}{c}\text { Insufficient }<30 \mathrm{ng} / \mathrm{mL} \\
\text { Deficient }<20 \mathrm{ng} / \mathrm{mL}\end{array}$ & Caucasian & $\begin{array}{l}\text { Vitamin D deficiency is not related to early } \\
\text { stages of autoimmune thyroiditis }\end{array}$ \\
\hline & Botelho et al. & [48] & 2018 & 159 & $30 \mathrm{ng} / \mathrm{dL}$ & NA & $\begin{array}{l}\text { Lower levels of Vitamin D have not been } \\
\text { associated with autoimmune thyroiditis }\end{array}$ \\
\hline \multicolumn{8}{|l|}{ MS } \\
\hline & Munger et al. & [49] & 2006 & 515 & $25 \mathrm{nmol} / \mathrm{L}$ & $\begin{array}{l}\text { White American, } \\
\text { Black and Hispanic } \\
\text { American }\end{array}$ & $\begin{array}{l}\text { High circulating levels of Vitamin D are } \\
\text { associated with a lower risk of MS }\end{array}$ \\
\hline & Munger et al. & [50] & 2017 & 1092 & $\begin{array}{c}\text { Normal }>50 \mathrm{nmol} / \mathrm{L}, \\
\text { Insufficient } 30-50 \mathrm{nmol} / \mathrm{L}, \\
\text { Deficient }<30 \mathrm{nmol} / \mathrm{L}\end{array}$ & Finnish females & Vitamin D deficiency is a risk factor for MS \\
\hline & Nielsen et al. & [51] & 2017 & 521 & $30 \mathrm{nmol} / \mathrm{L}$ & Danish & $\begin{array}{l}\text { Low concentrations of neonatal Vitamin D } \\
\text { are associated with an increased risk of MS }\end{array}$ \\
\hline & Ascherio et al. & [52] & 2014 & 468 & $50 \mathrm{nmol} / \mathrm{L}$ & NA & $\begin{array}{l}\text { Higher serum } 25(\mathrm{OH}) \mathrm{D} \text { levels robustly } \\
\text { predicted a lower degree of MS activity, } \\
\text { brain atrophy and clinical progression over } \\
\text { the } 5 \text { years of follow-up }\end{array}$ \\
\hline & Salzer et al. & [53] & 2012 & 192 & $75 \mathrm{nmol} / \mathrm{L}$ & NA & $\begin{array}{l}\text { Association between high } 25(\mathrm{OH}) \mathrm{D} \text { levels } \\
\text { during the years preceding disease onset } \\
\text { and a decreased risk of MS }\end{array}$ \\
\hline
\end{tabular}

NA, not applicable. 
Low Vitamin D levels in patients affected by SLE have been found [28-31,54-60], although evidence on the correlation between Vitamin D and disease activity is controversial, as well as the association with inflammatory cytokines and SLE serology [32,33]. A recent meta-analysis highlighted some SLE features that have been associated with Vitamin D deficiency, counting organ damage, SLE flares, neurological and renal involvement, thrombocytopenia, leukopenia, proteinuria, use of corticosteroids and hydroxychloroquine. It is important to note that the authors reported strong heterogeneity among the studies reviewed, which compromised the data analysis [34].

Low Vitamin D levels in SS patients have been documented as well [61-64]. Some authors reported that the disease severity was not associated with the extent of Vitamin D deficiency and suggested that the decrease in Vitamin D blood levels does not accelerate the worsening of the disease course [35]. Other authors confirmed these findings, excluding a correlation between Vitamin D levels and SS clinical and laboratory findings (i.e., disease duration, systemic involvement, autoantibodies) $[12,35,36]$.

Many studies assessed Vitamin D levels in RA patients, but disputed results have been reported [37-41]. A systematic review and meta-analyses on 3489 patients reported an inverse correlation between 25(OH)D levels and disease activity, which was stronger in studies from developing and low-latitude countries [42]. Some studies documented no significant differences between the RA patients and controls in terms of their $25(\mathrm{OH}) \mathrm{D}$ levels, and the correlation between $25(\mathrm{OH}) \mathrm{D}$ levels and the RA disease activity and joint damage, in these studies, has not been proven. However, it should be noted that these studies had a small sample size $[37,38]$.

Regarding Vitamin D status among autoimmune thyroid disease patients, multiple lines of evidence documented an association between low Vitamin D levels and disease onset $[43,45]$. However, other studies showed no significant differences in 25(OH)D levels between autoimmune thyroid disease patients and controls [46-48]. The relationship between Vitamin D status and the regulation of TSH, thyroid hormones, autoantibodies and immunological markers, including pro-inflammatory interleukins, is still debated. Furthermore, the clinical usefulness of serum $25(\mathrm{OH}) \mathrm{D}$ in predicting prognosis in these patients is controversial, and data on Vitamin D as a predictor of treatment response are limited.

In the end, low Vitamin D levels have been reported in patients affected by MS in both neonatal and adult cohorts [49-53,65-77]. Munger et al. measured serum 25(OH)D in more than 1000 women from the Finnish Maternity Cohort (FMC), finding that low $25(\mathrm{OH}) \mathrm{D}$ levels $(<30 \mathrm{nmol} / \mathrm{L})$ were associated with a higher MS risk, compared with normal levels $(\geq 50 \mathrm{nmol} / \mathrm{L})$. However, $25(\mathrm{OH}) \mathrm{D}$ levels were measured using a chemiluminescence assay [49], which is not an NIST-recommended RMP. Ascherio et al. performed 25(OH)D determinations in patients enrolled in the BENEFIT study, a large multi-center randomized trial. The authors showed that serum Vitamin D biomarker is a strong risk factor for long-term MS activity and progression in the early disease course, and it is able to predict new active lesions and relapse rate [50]. Collectively, it cannot be excluded that low Vitamin $\mathrm{D}$ levels could play a role in the early management of MS patients.

\subsection{Alzheimer's Disease and Parkinson's Disease}

$\mathrm{AD}$ and $\mathrm{PD}$ represent the most common neurodegenerative diseases worldwide. Accordingly, the role of Vitamin D has been widely investigated in patients affected by these diseases.

Vitamin D serum levels in AD patients have been largely explored [78-97]. Findings from a prospective study including 1658 individuals revealed that subjects having $25(\mathrm{OH}) \mathrm{D}$ insufficiency had a two-fold risk of AD onset, compared to those having Vitamin D sufficiency [98]. It should be noted that the authors carried out 25(OH)D measurements using RMPs and SRMs, which strengthens to the results. Similar findings have also been described by many studies [99-103]. In 2017, Licher et al. found that Vitamin D serum 25(OH)D concentrations below $25 \mathrm{nmol} / \mathrm{L}$ were associated with a higher incidence of 
AD [99]. Although a large sample size reinforced the study results (more than 3800 subjects), a chemi-luminescence assay was used for determination, achieving not standardized data as the results. In a large meta-analysis, Balion et al. reported an association between Vitamin D serum levels and AD development risk, but revealed remarkable discrepancies among the studies reviewed, highlighting that findings from these studies are weakened by differences in the assay methods and cut-offs used [103].

Many studies failed to demonstrate a correlation between Vitamin D and AD as well [104-109]. Olsson et al. [105] reported opposite findings in 1182 men, finding no association between $25(\mathrm{OH}) \mathrm{D}$ levels and the risk of $\mathrm{AD}$. It is important to note that NISTcertified assay methods were used to determine 25(OH)D serum levels by Olsson.

Karakis et al. reported no association between Vitamin D levels and incidence of AD in the Framingham Heart Study participants [106]. Although the 25(OH)D measurement in this study was performed by a competitive protein-binding immunoassay, the large sample size and long follow-up period conferred significance to the results. In line with the findings of Olsson and Karakis, Duchaine et al. reported no association between 25(OH)D levels and AD in 660 subjects from the Canadian Study of Health and Aging, although chemiluminescence assay methods were used for this study [107]. Surprisingly, the authors found that increased $25(\mathrm{OH}) \mathrm{D}$ concentrations were slightly associated with a higher risk of developing $\mathrm{AD}$ in women but not in men and suggested that further investigations are needed to look into the relationship with sex. Other authors confirmed that no relation exists between plasma $25(\mathrm{OH}) \mathrm{D}$ concentrations and the incidence of all-cause dementia or AD [108]. Another meta-analysis performed by Jayedi et al. on 27,000 individuals showed that Vitamin D insufficiency and deficiency are not correlated with the risk of developing $\mathrm{AD}[109]$ and confirmed that $25(\mathrm{OH}) \mathrm{D}$ levels $>35 \mathrm{ng} / \mathrm{mL}$ could increase AD risk.

Collectively, these findings could not be adequately homogeneous and robust to support a role for 25(OH)D as a biomarker in AD. Additionally, well-established biomarkers have been validated for AD diagnosis and prognosis and are successfully used in clinical practice [110-113].

Some studies have reported low Vitamin D serum levels among PD patients [114-116]. One longitudinal, long-term follow-up study was performed on $>3100$ subjects by Knekt et al. in 2010 [117]. The authors reported the use of SRM certified by NIST, and findings suggested that $25(\mathrm{OH}) \mathrm{D}$ could predict the risk of PD development [117]. However, the small number of PD cases in the sample $(n=50)$ and the possible presence of residual confounders limited the strengths of the findings achieved. Other authors documented a significant association between $25(\mathrm{OH}) \mathrm{D}$ serum levels and disease severity $[118,119]$, and two recent and extensive meta-analyses confirmed these results $[120,121]$. It should be noted that strong discrepancies were reported among the studies in the assay methods used, which requires interpreting findings from these meta-analyses with a grain of salt.

\subsection{Psychiatric Diseases}

Many studies documented an inverse association between 25(OH)D serum levels and major depression disorder (MDD) [122-127], although opposite findings have been reported as well [84-88].

Data from the European Male Ageing Study (EMAS), involving 3151 men, revealed that serum $25(\mathrm{OH}) \mathrm{D}$ levels were significantly lower $(p<0.001)$ in depressed men compared with non-depressed participants [122], and this association remained significant after adjusting for age, alcohol consumption, physical activity, BMI, physical function and comorbidities. The Korean Urban Rural Elderly (KURE) study was performed on 2942 participants and showed that serum 25(OH)D concentrations were inversely associated with the presence of depressive symptoms in men, but not in women [125]. Despite such evidence, several authors failed to prove the association between serum $25(\mathrm{OH}) \mathrm{D}$ levels and MDD [126-132].

Several authors have proved an association between low serum 25(OH)D levels and schizophrenia, and the relationship between disease severity and Vitamin D circulating 
levels has also been documented [133-135]. Nonetheless, opposite findings have been also reported [136]. A recent meta-analysis on 12,528 participants assessed the relationship between schizophrenia and Vitamin D levels, concluding that schizophrenia onset is more likely among patients with Vitamin D deficiency/insufficiency compared to controls [137]. In addition, cross-sectional studies and those involving outpatients showed significant differences of mean Vitamin D serum levels between schizophrenic patients and controls more frequently than case-control studies and those performed on inpatient populations [137]. However, many drawbacks affected the studies reviewed (selection bias, observational study set, presence of confounders, lack of information on patients' baseline characteristics, differences among the cut-offs used to define Vitamin D insufficiency and deficiency), leading to a need to interpret findings with caution. Table 2 summarizes the main studies performed on psychiatric disorders.

Table 2. Major findings from the observational studies evaluating Vitamin D serum levels in psychiatric disorders.

\begin{tabular}{|c|c|c|c|c|c|c|c|}
\hline Disease & Authors & Ref & $\begin{array}{l}\text { Publication } \\
\text { Time }\end{array}$ & $\begin{array}{l}\text { Sample } \\
\text { Size }\end{array}$ & $\begin{array}{l}\text { Cut-Off Value for } \\
\text { Vitamin D }\end{array}$ & $\begin{array}{l}\text { Ethnic/Cultural/ } \\
\text { Geographical } \\
\text { Features }\end{array}$ & Findings \\
\hline \multicolumn{8}{|l|}{ MDD } \\
\hline & Lee et al. & [122] & 2011 & 3369 & $\begin{array}{c}\text { Sufficient }>75 \mathrm{nmol} / \mathrm{L} \\
\text { Sub-optimum } 50-74.9 \\
\text { nmol/L } \\
\text { Insufficient } 25-49.9 \\
\text { nmol/L } \\
\text { Deficient }<25 \text { nom } / \mathrm{L}\end{array}$ & Caucasian & $\begin{array}{l}\text { An inverse association } \\
\text { between } 25(\mathrm{OH}) \mathrm{D} \text { levels } \\
\text { and depression, largely } \\
\text { independent of several } \\
\text { lifestyle and health factors }\end{array}$ \\
\hline & $\begin{array}{l}\text { Kjaergaard } \\
\text { et al. }\end{array}$ & [123] & 2012 & 357 & NA & Norway & $\begin{array}{l}\text { Low levels of serum } \\
\text { 25(OH)D were associated } \\
\text { with depressive } \\
\text { symptoms, but no effect } \\
\text { was found with Vitamin D } \\
\text { supplementation. }\end{array}$ \\
\hline & $\begin{array}{l}\text { Milaneschi } \\
\text { et al. }\end{array}$ & [124] & 2014 & 2386 & $\begin{array}{l}\text { Optimal }>50 \mathrm{nmol} / \mathrm{L} \\
\text { Insufficient } 25-50 \mathrm{nmol} / \mathrm{L} \\
\text { Deficient }<25 \mathrm{nmol} / \mathrm{L}\end{array}$ & Netherlands & $\begin{array}{l}\text { Low levels of } 25(\mathrm{OH}) \mathrm{D} \\
\text { were associated with } \\
\text { the presence and severity of } \\
\text { depressive disorder }\end{array}$ \\
\hline & Song et al. & [125] & 2016 & 2853 & NA & Korea & $\begin{array}{l}\text { Lower concentrations of } \\
\text { Vitamin D are } \\
\text { independently associated } \\
\text { with depressive symptoms }\end{array}$ \\
\hline & $\begin{array}{l}\text { Sherchand } \\
\text { et al. }\end{array}$ & [126] & 2018 & 300 & $\begin{array}{l}\text { Insufficient } 20-29 \mathrm{ng} / \mathrm{mL} \\
\text { Sufficient } 30-100 \mathrm{ng} / \mathrm{mL} \\
\text { Deficient }<20 \mathrm{ng} / \mathrm{mL}\end{array}$ & Nepal & $\begin{array}{l}\text { Vitamin D deficient people } \\
\text { have increased odds of } \\
\text { having clinically significant } \\
\text { depression }\end{array}$ \\
\hline & $\begin{array}{l}\text { Vidgren et al. } \\
2018\end{array}$ & [127] & 2018 & 1602 & NA & Finland & $\begin{array}{l}\text { Lower concentration of } \\
\text { serum } 25(\mathrm{OH}) \mathrm{D} \text { is } \\
\text { associated with a higher } \\
\text { prevalence of depression in } \\
\text { an elderly general } \\
\text { population }\end{array}$ \\
\hline & Zhao et al. & [128] & 2010 & 3916 & NA & USA & $\begin{array}{l}\text { No association between } \\
\text { serum concentrations of } \\
\text { 25(OH)D and the presence } \\
\text { of moderate-to-severe } \\
\text { depression, major } \\
\text { depression or minor } \\
\text { depression }\end{array}$ \\
\hline
\end{tabular}


Table 2. Cont.

\begin{tabular}{|c|c|c|c|c|c|c|c|}
\hline Disease & Authors & Ref & $\begin{array}{l}\text { Publication } \\
\text { Time }\end{array}$ & $\begin{array}{l}\text { Sample } \\
\text { Size }\end{array}$ & $\begin{array}{l}\text { Cut-Off Value for } \\
\text { Vitamin D }\end{array}$ & $\begin{array}{l}\text { Ethnic/Cultural/ } \\
\text { Geographical } \\
\text { Features }\end{array}$ & Findings \\
\hline & Kwasky et al. & [129] & 2014 & 77 & NA & USA & $\begin{array}{l}\text { No association between } \\
\text { Vitamin D and depression }\end{array}$ \\
\hline & Can et al. & [130] & 2017 & 175 & NA & Turkey & $\begin{array}{l}\text { No relationship between } \\
\text { depression, Vitamin D } \\
\text { levels and Fok } 1 \\
\text { polymorphism of Vitamin } \\
\text { D receptor. }\end{array}$ \\
\hline & Bossola et al. & [131] & 2010 & 80 & NA & Italy & $\begin{array}{l}\text { No association between } \\
\text { Vitamin } \mathrm{D} \text { and symptoms } \\
\text { of depression as well as } \\
\text { anxiety in chronic } \\
\text { hemodialysis patients }\end{array}$ \\
\hline & Almeida et al. & [132] & 2015 & 3105 & $<50 \mathrm{nmol} / \mathrm{L}$ & Australia & $\begin{array}{l}\text { The results do not support } \\
\text { a role for Vitamin D in the } \\
\text { causation of depression }\end{array}$ \\
\hline \multicolumn{8}{|c|}{ Schizophrenia } \\
\hline & Berg et al. & [133] & 2010 & 1179 & $\begin{array}{c}\text { Insufficient } / \text { deficient }< \\
50 \mathrm{nmol} / \mathrm{L}\end{array}$ & $\begin{array}{l}\text { Norway and } \\
\text { immigrants }\end{array}$ & $\begin{array}{l}\text { 25-hydroxyvitamin D } \\
\text { deficiency is common in } \\
\text { patients with psychotic } \\
\text { disorders }\end{array}$ \\
\hline & Crews et al. & [134] & 2013 & 69 & $\begin{array}{l}\text { Insufficient } 25-50 \mathrm{nmol} / \mathrm{L} \\
\text { Deficient }<25 \mathrm{nmol} / \mathrm{L}\end{array}$ & England & $\begin{array}{l}\text { Vitamin D levels are low at } \\
\text { the onset of a first psychotic } \\
\text { episode }\end{array}$ \\
\hline & Firth et al. & [135] & 2018 & 2612 & NA & $\begin{array}{l}\text { Spain, Turkey, } \\
\text { India, Poland, } \\
\text { China, UK, USA, } \\
\text { Pakistan, } \\
\text { Singapore, } \\
\text { Nigeria, } \\
\text { Romania, } \\
\text { Norway }\end{array}$ & $\begin{array}{l}\text { Deficits in Vitamin D } \\
\text { previously observed in } \\
\text { long-term schizophrenia } \\
\text { appear to exist from illness } \\
\text { onset, and are associated } \\
\text { with worse symptomology }\end{array}$ \\
\hline & Norelli et al. & [136] & 2010 & 60 & $\begin{array}{c}\text { Deficient }<20 \mathrm{ng} / \mathrm{mL} \\
\text { Insufficient } 20-29 \mathrm{ng} / \mathrm{mL} \\
\text { Optimal }>30 \mathrm{ng} / \mathrm{mL}\end{array}$ & USA & $\begin{array}{l}\text { High prevalence rates of } \\
\text { Vitamin D deficiency in the } \\
\text { general population, } \\
\text { including patients with } \\
\text { schizophrenia-spectrum } \\
\text { disorders regardless of } \\
\text { acute care or long-stay } \\
\text { inpatient status. }\end{array}$ \\
\hline & Zhu et al. & [137] & 2020 & 12,528 & NA & $\begin{array}{l}\text { Africa, America, } \\
\text { Caucasian, Japan, } \\
\text { Germany, Spain, } \\
\text { Turkey, Pakistan }\end{array}$ & $\begin{array}{l}\text { Vitamin D deficiency is } \\
\text { associated with } \\
\text { schizophrenia }\end{array}$ \\
\hline
\end{tabular}

NA, not available.

\section{Studies on Vitamin D Supplementation}

A debated matter is whether low Vitamin D levels could be a modifiable risk factor for neurological and autoimmune diseases. Interventional studies are the most suitable to assess whether any molecule or its deficiency can expose a patient to the onset of a certain disease. To establish whether the optimal Vitamin D status could prevent the onset or modify the course of neurological, psychiatric and autoimmune diseases, supplementation studies have been performed.

In autoimmune diseases patients, Vitamin $\mathrm{D}$ supplementation has been proven to ameliorate RA symptoms, such as pain, but evidence on a beneficial effect of Vitamin D supplementation in these patients is limited and needs to be further confirmed [138-140]. Some authors reported cholecalciferol supplementation to be effective in decreasing disease activity and reducing fatigue in juvenile SLE patients $[141,142]$. However, other studies 
documented a modest beneficial effect of supplementation in improving disease activity in adult SLE patients. Regarding the effect of Vitamin D supplementation in MS patients, a recent meta-analysis summarized findings from six RCTs to assess the impact of Vitamin $\mathrm{D}$ administration on the severity and progression of MS, as defined according to the Expanded Disability Status Scale (EDSS) [143]. The authors showed that different dosages and formulations of Vitamin D did not affect EDSS, compared to the placebo. Similar findings were achieved by Zheng et al. in an earlier meta-analysis demonstrating that Vitamin D administration had no effect on MS severity and progression according to the EDSS score and the annual relapse rate (ARR) [144]. Recently, Quirant-Sánchez et al. showed that a combined therapy based on the use of Vitamin D3 and tolerogenic dendritic cells (tolDC) plus interferon beta in a preclinical model of MS ameliorated the disease course compared to each monotherapy. Thus, a combined therapy based on antigen-specific VitD3tolDC and IFN-beta could represent a promising strategy for MS [145].

In neurodegenerative diseases, questionable results have been gained as well. Some authors evaluated the effect of Vitamin D supplementation in preventing the onset of AD, achieving controversial evidence [146,147]. It should be noted that studies proving an impact of Vitamin D supplementation in cognition had limited populations and follow-up duration; therefore, no clear evidence of a significant influence of low Vitamin D levels on the risk of cognitive decline onset has been earned. Further, a recent RCT performed in critically ill adults with Vitamin D deficiency confirmed that supplementation does not improve cognition and executive function [148].

Likewise, data on the impact of Vitamin D supplementation in preventing PD onset are inconclusive and few, with evidence proving that supplementation has no beneficial effect on motor function in PD patients [121,144]. In 2019, Zhou et al. reported findings from a systematic review documenting no beneficial influence in motor function in PD patients after Vitamin D supplementation. However, the study displayed some drawbacks, counting a small number of study participants and short-term follow-up, which may have affected the results [121]. Oppositely, other authors reported that Vitamin D administration had an effect on the strength and postural balance in these patients, and, interestingly, an impact of Vitamin D supplementation has been documented on disease progression in PD patients carrying CT and TT genotypes of FokI, a VDR gene polymorphism [149-152].

A critical matter regarding Vitamin D supplementation is that a remarkable difference among individuals exists as per the response to Vitamin D analogues. Such a difference mainly depends on VDBP genetic variants, which sharply influence the $25(\mathrm{OH}) \mathrm{D}$ circulating levels, with VDBP being the Vitamin D carrier protein. For instance, Al Daghri et al. reported two single nucleotide polymorphisms (SNPs), rs4588 and rs7041, increasing the risk of non-response to Vitamin D supplementation, regardless of the administered doses [153].

\section{Conclusions}

Vitamin $\mathrm{D}$ is one of the most studied vitamins worldwide and its biological activity in humans is still a captivating topic. Low Vitamin D levels occur among neurological, psychiatric and autoimmune patients, but the significance of such findings is far from being clear, either because low Vitamin D levels are common among healthy subjects, or because studies display several drawbacks that sharply weaken the significance of the results achieved. The main pitfalls can be summarized in two different categories: (i) analytical items, concerning laboratory choices of the assay methods used for $25(\mathrm{OH}) \mathrm{D}$ measurement, and (ii) methodological issues, regarding the conceptualization and design of the study. From a strictly laboratory perspective, the former affects the reliability and reproducibility of the $25(\mathrm{OH}) \mathrm{D}$ measurement, and refers to the standardization issue, which has been deeply faced in the past decades without full success. In this regard, it should be taken into account that standardized assay methods are often expensive and not rapidto-perform, which hampers their use among healthcare systems and research laboratories. Regarding methodological issues, the discrepancies in the cut-offs used made it difficult 
to pool data, to the extent that most of the meta-analyses reviewed in the current article suggested interpreting findings with caution. In addition, the study set had a major role in weakening the significance of the results in some cases; for instance, short follow-up period longitudinal studies are not suitable for difficult-to-diagnose diseases such as AD.

The current review has some limitations as well, including that it is not a systematic review and it takes into account only a part of the autoimmune, psychiatric and neurodegenerative diseases. Despite such limitations, it points out that Vitamin D's role as a biomarker in these diseases, based on the studies reviewed, has not been proven. Although some authors reported that serum $25(\mathrm{OH}) \mathrm{D}$ is able to facilitate diagnosis and prognosis in $\mathrm{AD}, \mathrm{PD}$ and some autoimmune pathologies, no evidence supports its use as a candidate marker for entering clinical practice. Additional concerns have been raised considering that autoimmune and neurodegenerative diseases already benefit from established biomarkers.

Advancing knowledge in this field means correcting analytical and methodological issues, providing $25(\mathrm{OH}) \mathrm{D}$ standardized data and producing meta-analyses with robust data and significance. The main goal for future investigations in this scenario is to address the following question: can $25(\mathrm{OH}) \mathrm{D}$ measurement have an influence on the clinical management of psychiatric patients, or in autoimmune and neurodegenerative ones?

Another big challenge in this area is around the supplementation of Vitamin D. In AD patients, it is not clear yet how and if Vitamin D appropriate status can help prevent disease onset or ameliorate disease features, despite the relatively large amount of studies that have been performed. Generally, interventional studies are arduous to perform compared to the observational ones, due to high costs, ethic concerns, long time span and other elements. In addition, some apparent difficulties affect RCTs on Vitamin D supplementation, including the toxicity of Vitamin D analogues and the variability of the response due to genetic factors. The main goal for future investigations would be a sort of mapping of the factors influencing the effectiveness of supplementation, to identify patients having benefits from Vitamin D analogues' administration. This could help move the knowledge on Vitamin D toward clinical practice real-world needs.

Author Contributions: Conceptualization, G.B. and M.C.; writing—original draft preparation, G.B. and C.M.G.; data curation, R.V.G.; writing - review and editing, C.S., L.A. and B.L.S.; and supervision, M.C. All authors have read and agreed to the published version of the manuscript.

Funding: This research received no external funding.

Institutional Review Board Statement: Not applicable.

Informed Consent Statement: Not applicable.

Data Availability Statement: Not applicable.

Conflicts of Interest: The authors declare no conflict of interest.

\section{References}

1. Bikle, D.; Christakos, S. New aspects of vitamin D metabolism and action-Addressing the skin as source and target. Nat. Rev. Endocrinol. 2020, 16, 234-252. [CrossRef] [PubMed]

2. Holick, M.F.; Binkley, N.C.; Bischoff-Ferrari, H.A.; Gordon, C.M.; Hanley, D.A.; Heaney, R.P.; Murad, M.H.; Weaver, C.M. Evaluation, treatment, and prevention of vitamin D deficiency: An Endocrine Society clinical practice guideline. J. Clin. Endocrinol. Metab. 2011, 96, 1911-1930. [CrossRef] [PubMed]

3. Lin, Z.; Li, W. The Roles of Vitamin D and Its Analogs in Inflammatory Diseases. Curr. Top. Med. Chem. 2016, $16,1242-1261$. [CrossRef] [PubMed]

4. Mak, A. The Impact of Vitamin D on the Immunopathophysiology, Disease Activity, and Extra-Musculoskeletal Manifestations of Systemic Lupus Erythematosus. Int. J. Mol. Sci. 2018, 19, 2355. [CrossRef] [PubMed]

5. Bivona, G.; Agnello, L.; Pivetti, A.; Milano, S.; Scazzone, C.; Sasso, B.L.; Ciaccio, M. Association between hypovitaminosis D and systemic sclerosis: True or fake? Clin. Chim. Acta 2016, 458, 115-119. [CrossRef] [PubMed]

6. Miller, J.W.; Harvey, D.J.; Beckett, L.A.; Green, R.; Farias, S.T.; Reed, B.R.; Olichney, J.M.; Mungas, D.M.; DeCarli, C. Vitamin D Status and Rates of Cognitive Decline in a Multiethnic Cohort of Older Adults. JAMA Neurol. 2015, 72, 1295-1303. [CrossRef]

7. Bikle, D.D.; Patzek, S.; Wang, Y. Physiologic and pathophysiologic roles of extra renal CYP27b1: Case report and review. Bone Rep. 2018, 8, 255-267. [CrossRef] 
8. Bivona, G.; Agnello, L.; Ciaccio, M. The immunological implication of the new vitamin D metabolism. Cent. Eur. J. Immunol. 2018, 43, 331-334. [CrossRef]

9. Bikle, D.D.; Schwartz, J. Vitamin D Binding Protein, Total and Free Vitamin D Levels in Different Physiological and Pathophysiological Conditions. Front. Endocrinol. 2019, 10, 317. [CrossRef]

10. Prabhu, A.V.; Luu, W.; Li, D.; Sharpe, L.J.; Brown, A.J. DHCR7: A vital enzyme switch between cholesterol and vitamin D production. Prog. Lipid Res. 2016, 64, 138-151. [CrossRef]

11. Bivona, G.; Gambino, C.M.; Iacolino, G.; Ciaccio, M. Vitamin D and the nervous system. Neurol. Res. 2019, 41, 827-835. [CrossRef]

12. Bivona, G.; Agnello, L.; Bellia, C.; Iacolino, G.; Scazzone, C.; Lo Sasso, B.; Ciaccio, M. Non-Skeletal Activities of Vitamin D: From Physiology to Brain Pathology. Medicina 2019, 55, 341. [CrossRef] [PubMed]

13. Meyer, M.B.; Benkusky, N.A.; Kaufmann, M.; Lee, S.M.; Onal, M.; Jones, G.; Pike, J.W. A kidney-specific genetic control module in mice governs endocrine regulation of the cytochrome P450 gene Cyp27b1 essential for vitamin D3 activation. J. Biol. Chem. 2017, 292, 17541-17558. [CrossRef]

14. Scazzone, C.; Agnello, L.; Ragonese, P.; Lo Sasso, B.; Bellia, C.; Bivona, G.; Schillaci, R.; Salemi, G.; Ciaccio, M. Association of CYP2R1 rs10766197 with MS risk and disease progression. J. Neurosci. Res. 2018, 96, 297-304. [CrossRef]

15. Bivona, G.; Lo Sasso, B.; Iacolino, G.; Gambino, C.M.; Scazzone, C.; Agnello, L.; Ciaccio, M. Standardized measurement of circulating vitamin $\mathrm{D}[25(\mathrm{OH}) \mathrm{D}]$ and its putative role as a serum biomarker in Alzheimer's disease and Parkinson's disease. Clin. Chim. Acta 2019, 497, 82-87. [CrossRef] [PubMed]

16. Binkley, N.; Sempos, C.T. Vitamin D Standardization Program (VDSP). Standardizing vitamin D assays: The way forward. J. Bone Miner. Res. 2014, 29, 1709-1714. [CrossRef]

17. Rabenberg, M.; Scheidt-Nave, C.; Busch, M.A.; Thamm, M.; Rieckmann, N.; Durazo-Arvizu, R.A.; Dowling, K.G.; Škrabáková, Z.; Cashman, K.D.; Sempos, C.T.; et al. Implications of standardization of serum 25-hydroxyvitamin D data for the evaluation of vitamin D status in Germany, including a temporal analysis. BMC Public Health 2018, 18, 845. [CrossRef]

18. Cashman, K.D.; Kiely, M.; Kinsella, M.; Durazo-Arvizu, R.A.; Tian, L.; Zhang, Y.; Lucey, A.; Flynn, A.; Gibney, M.J.; Vesper, H.W.; et al. Evaluation of Vitamin D Standardization Program protocols for standardizing serum 25-hydroxyvitamin D data: A case study of the program's potential for national nutrition and health surveys. Am. J. Clin. Nutr. 2013, 97, 1235-1242. [CrossRef] [PubMed]

19. Cashman, K.D.; Dowling, K.G.; Škrabáková, Z.; Kiely, M.; Lamberg-Allardt, C.; Durazo-Arvizu, R.A.; Sempos, C.T.; Koskinen, S.; Lundqvist, A.; Sundvall, J.; et al. Standardizing serum 25-hydroxyvitamin D data from four Nordic population samples using the Vitamin D Standardization Program protocols: Shedding new light on vitamin D status in Nordic individuals. Scand. J. Clin. Lab Investig. 2015, 75, 549-561. [CrossRef]

20. Jones, G.R.; Jackson, C. The Joint Committee for Traceability in Laboratory Medicine (JCTLM) - Its history and operation. Clin. Chim. Acta 2016, 453, 86-94. [CrossRef]

21. Carter, G.D.; Berry, J.; Durazo-Arvizu, R.; Gunter, E.; Jones, G.; Jones, J.; Makin, H.; Pattni, P.; Sempos, C.T.; Twomey, P.; et al. Hydroxyvitamin D assays: An historical perspective from DEQAS. J. Steroid Biochem. Mol. Biol. 2018, 177, 30-35. [CrossRef]

22. Binkley, N.; Dawson-Hughes, B.; Durazo-Arvizu, R.; Thamm, M.; Tian, L.; Merkel, J.M.; Jones, J.C.; Carter, G.D.; Sempos, C.T. Vitamin D measurement standardization: The way out of the chaos. J. Steroid Biochem. Mol. Biol. 2017, 173, 117-121. [CrossRef] [PubMed]

23. Durazo-Arvizu, R.A.; Ahmed, F.; Berry, J.; Cavalier, E.; Gunter, E.; Jones, G.; Jones, J.; Sempos, C.T.; Twomey, P.J.; Williams, E.L.; et al. Estimating uncertainty of target values for DEQAS serum materials. J. Steroid Biochem. Mol. Biol. 2019, 188, 90-94. [CrossRef] [PubMed]

24. Burdette, C.Q.; Camara, J.E.; Nalin, F.; Pritchett, J.; Sander, L.C.; Carter, G.D.; Jones, J.; Betz, J.M.; Sempos, C.T.; Wise, S.A. Establishing an Accuracy Basis for the Vitamin D External Quality Assessment Scheme (DEQAS). J. AOAC Int. 2017, 100, 1277-1287. [CrossRef]

25. Agnello, L.; Bellia, C.; Lo Sasso, B.; Pivetti, A.; Muratore, M.; Scazzone, C.; Bivona, G.; Lippi, G.; Ciaccio, M. Establishing the upper reference limit of Galectin-3 in healthy blood donors. Biochem. Med. 2017, 27, 030709. [CrossRef]

26. Agnello, L.; Bellia, C.; Scazzone, C.; Bivona, G.; Iacolino, G.; Gambino, C.M.; Muratore, M.; Lo Sasso, B.; Ciaccio, M. Establishing the 99(th) percentile for high sensitivity cardiac troponin I in healthy blood donors from Southern Italy. Biochem. Med. 2019, 29, 020901. [CrossRef]

27. Agnello, L.; Lo Sasso, B.; Bivona, G.; Gambino, C.M.; Giglio, R.V.; Iacolino, G.; Iacona, A.; Mancuso, S.; Ciaccio, A.M.; Vidali, M.; et al. Reference interval of monocyte distribution width (MDW) in healthy blood donors. Clin. Chim. Acta 2020, 510, $272-277$. [CrossRef] [PubMed]

28. Petri, M.; Bello, K.J.; Fang, H.; Magder, L.S. Vitamin D in systemic lupus erythematosus:modest association with disease activity and the urine protein-to-creatinine ratio. Arthritis Rheum. 2013, 65, 1865-1871. [CrossRef]

29. AlSaleem, A.; AlE'ed, A.; AlSaghier, A.; Al-Mayouf, S.M. Vitamin D status in childrenwith systemic lupus erythematosus and its association with clinical and laboratoryparameters. Clin. Rheumatol. 2015, 34, 81-84. [CrossRef]

30. Eloi, M.; Horvath, D.V.; Ortega, J.C.; Prado, M.S.; Andrade, L.E.; Szejnfeld, V.L.; de Moura Castro, C.H. 25-Hydroxivitamin D Serum Concentration, Not Free and Bioavailable Vitamin D, Is Associated with Disease Activity in Systemic Lupus Erythematosus Patients. PLoS ONE 2017, 12, e0170323. [CrossRef] 
31. Salman-Monte, T.C.; Torrente-Segarra, V.; Almirall, M.; Corzo, P.; Mojal, S.; Carbonell-Abelló, J. Prevalence and predictors of vitamin D insufficiency in supplemented and non-supplemented women with systemic lupus erythematosus in the Mediterranean region. Rheumatol. Int. 2016, 36, 975-985. [CrossRef]

32. Andreoli, L.; Piantoni, S.; Dall'Ara, F.; Allegri, F.; Meroni, P.L.; Tincani, A. Vitamin D and antiphospholipid syndrome. Lupus 2012, 21, 736-740. [CrossRef]

33. Aranow, C.; Kamen, D.L.; Dall'Era, M.; Massarotti, E.M.; Mackay, M.C.; Koumpouras, F.; Coca, A.; Chatham, W.W.; Clowse, M.E.; Criscione-Schreiber, L.G.; et al. Randomized, Double-Blind, Placebo-Controlled Trial of the Effect of Vitamin D3 on the Interferon Signature in Patients with Systemic Lupus Erythematosus. Arthritis Rheumatol. 2015, 67, 1848-1857. [CrossRef]

34. Dall'Ara, F.; Cutolo, M.; Andreoli, L.; Tincani, A.; Paolino, S. Vitamin D and systemic lupus erythematous: A review of immunological and clinical aspects. Clin. Exp. Rheumatol. 2018, 36, 153-162. [PubMed]

35. An, L.; Sun, M.H.; Chen, F.; Li, J.R. Vitamin D levels in systemic sclerosis patients: A meta-analysis. Drug Des. Devel. Ther. 2017, 11, 3119-3125. [CrossRef]

36. Gupta, S.; Mahajan, V.K.; Yadav, R.S.; Mehta, K.S.; Bhushan, S.; Chauhan, P.S.; Rawat, R.; Sharma, V. Evaluation of Serum Vitamin D Levels in Patients with Systemic Sclerosis and Healthy Controls: Results of a Pilot Study. Indian Dermatol. Online J. 2018, 9, 250-255.

37. Polasik, K.; Piotrowska, E.; Lipińska, B.; Witkowski, J.M.; Bryl, E.; Tukaj, S. Vitamin D status in patients with rheumatoid arthritis: A correlation analysis with disease activity and progression, as well as serum IL-6 levels. Acta Biochim. Pol. 2017, 64, 667-670. [CrossRef]

38. Wong, T.H.; Gupta, E.D.; Radhakrishnan, A.K.; Gun, S.C.; Chembalingam, G.; Yeap, S.S. Effects of 25-hydroxyvitamin D and vitamin D-binding protein on bone mineral density and disease activity in Malaysian patients with rheumatoid arthritis. Int. J. Rheum. Dis. 2018, 21, 992-1000. [CrossRef] [PubMed]

39. Kerr, G.S.; Sabahi, I.; Richards, J.S.; Caplan, L.; Cannon, G.W.; Reimold, A.; Thiele, G.M.; Johnson, D.; Mikuls, T.R. Prevalence of vitamin D insufficiency/deficiency in rheumatoid arthritis and associations with disease severity and activity. J. Rheumatol. 2011, 38, 53-59. [CrossRef]

40. Pakchotanon, R.; Chaiamnuay, S.; Narongroeknawin, P.; Asavatanabodee, P. The association between serum vitamin D Level and disease activity in Thai rheumatoid arthritis patients. Int. J. Rheum. Dis. 2016, 19, 355-361. [CrossRef] [PubMed]

41. Gopal, K.; Thevarajah, M.; Ng, C.M.; Raja, J. Effects of vitamin D on disease activity and serum interleukin-6 in rheumatoid arthritis. Int. J. Rheum. Dis. 2019, 22, 834-841. [CrossRef]

42. Lin, J.; Liu, J.; Davies, M.L.; Chen, W. Serum Vitamin D Level and Rheumatoid Arthritis Disease Activity: Review and MetaAnalysis. PLoS ONE 2016, 11, e0146351. [CrossRef]

43. Wang, J.; Lv, S.; Chen, G.; Gao, C.; He, J.; Zhong, H.; Xu, Y. Meta-analysis of the association between vitamin D and autoimmune thyroid disease. Nutrients 2015, 7, 2485-2498. [CrossRef] [PubMed]

44. Muscogiuri, G.; Palomba, S.; Caggiano, M.; Tafuri, D.; Colao, A.; Orio, F. Low $25(\mathrm{OH})$ vitamin D levels are associated with autoimmune thyroid disease in polycysticovary syndrome. Endocrine 2016, 53, 538-542. [CrossRef]

45. Muscogiuri, G.; Mari, D.; Prolo, S.; Fatti, L.M.; Cantone, M.C.; Garagnani, P.; Arosio, B.; Di Somma, C.; Vitale, G. Hydroxyvitamin D Deficiency and Its Relationship to Autoimmune Thyroid Disease in the Elderly. Int. J. Environ. Res. Public Health 2016, 13, 850. [CrossRef]

46. D'Aurizio, F.; Villalta, D.; Metus, P.; Doretto, P.; Tozzoli, R. Is vitamin D a player or not in the pathophysiology of autoimmune thyroid diseases? Autoimmun. Rev. 2015, 14, 363-369. [CrossRef]

47. Effraimidis, G.; Badenhoop, K.; Tijssen, J.G.; Wiersinga, W.M. Vitamin D deficiency is not associated with early stages of thyroid autoimmunity. Eur. J. Endocrinol. 2012, 167, 43-48. [CrossRef]

48. Botelho, I.; Moura Neto, A.; Silva, C.A.; Tambascia, M.A.; Alegre, S.M.; Zantut-Wittmann, D.E. Vitamin D in Hashimoto's thyroiditis and its relationship with thyroid function and inflammatory status. Endocr. J. 2018, 65, 1029-1037. [CrossRef] [PubMed]

49. Munger, K.L.; Levin, L.I.; Hollis, B.W.; Howard, N.S.; Ascherio, A. Serum 25-hydroxyvitamin D levels and risk of multiple sclerosis. JAMA 2006, 296, 2832-2838. [CrossRef] [PubMed]

50. Munger, K.L.; Hongell, K.; Åivo, J.; Soilu-Hänninen, M.; Surcel, H.M.; Ascherio, A. 25-Hydroxyvitamin D deficiency and risk of MS among women in the Finnish Maternity Cohort. Neurology 2017, 89, 1578-1583. [CrossRef]

51. Nielsen, N.M.; Munger, K.L.; Koch-Henriksen, N.; Hougaard, D.M.; Magyari, M.; Jørgensen, K.T.; Lundqvist, M.; Simonsen, J.; Jess, T.; Cohen, A.; et al. Neonatal vitamin D status and risk of multiple sclerosis: A population-based case-control study. Neurology 2017, 88, 44-51. [CrossRef] [PubMed]

52. Ascherio, A.; Munger, K.L.; White, R.; Köchert, K.; Simon, K.C.; Polman, C.H.; Freedman, M.S.; Hartung, H.P.; Miller, D.H.; Montalbán, X.; et al. Vitamin D as an early predictor of multiple sclerosis activity and progression. JAMA Neurol. 2014, 71, 306-314. [CrossRef] [PubMed]

53. Salzer, J.; Hallmans, G.; Nystrom, M.; Stenlund, H.; Wadell, G.; Sundstrom, P. Vitamin D as a protective factor in multiple sclerosis Neurology 2012, 79, 2140-2214. [CrossRef]

54. Islam, M.A.; Khandker, S.S.; Alam, S.S.; Kotyla, P.; Hassan, R. Vitamin D status in patients with systemic lupus erythematosus (SLE): A systematic review and meta-analysis. Autoimmun. Rev. 2019, 18, 102392. [CrossRef] 
55. Murdaca, G.; Tonacci, A.; Negrini, S.; Greco, M.; Borro, M.; Puppo, F.; Gangemi, S. Emerging role of vitamin D in autoimmune diseases: An update on evidence and therapeutic implications. Autoimmun. Rev. 2019, 18, 102350. [CrossRef] [PubMed]

56. Durcan, L.; Petri, M. Immunomodulators in SLE: Clinical evidence and immunologic actions. J. Autoimmun. 2016, 74, 73-84. [CrossRef]

57. Nguyen, M.H.; Bryant, K.; O'Neill, S.G. Vitamin D in SLE: A role in pathogenesis and fatigue? A review of the literature. Lupus 2018, 27, 2003-2011. [CrossRef]

58. Azrielant, S.; Shoenfeld, Y. Eppur Si Muove: Vitamin D is essential in preventing and modulating SLE. Lupus 2016, 25, 563-572. [CrossRef] [PubMed]

59. Alele, J.D.; Kamen, D.L. The importance of inflammation and vitamin D status in SLE-associated osteoporosis. Autoimmun. Rev. 2010, 9, 137-139. [CrossRef] [PubMed]

60. Shoenfeld, Y.; Giacomelli, R.; Azrielant, S.; Berardicurti, O.; Reynolds, J.A.; Bruce, I.N. Vitamin D and systemic lupus erythematosus-The hype and the hope. Autoimmun. Rev. 2018, 17, 19-23. [CrossRef]

61. Vacca, A.; Cormier, C.; Mathieu, A.; Kahan, A.; Allanore, Y. Vitamin D levels and potential impact in systemic sclerosis. Clin. Exp. Rheumatol. 2011, 29, 1024-1031.

62. Isola, G.; Palazzo, G.; Polizzi, A.; Murabito, P.; Giuffrida, C.; Lo Gullo, A. Association of Systemic Sclerosis and Periodontitis with Vitamin D Levels. Nutrients 2021, 13, 705. [CrossRef] [PubMed]

63. Diaconu, A.D.; Ostafie, I.; Ceasovschih, A.; Șorodoc, V.; Lionte, C.; Ancuța, C.; \& Șorodoc, L. Role of Vitamin D in Systemic Sclerosis: A Systematic Literature Review. J Immunol. Res. 2021, 2021, 9782994. [CrossRef] [PubMed]

64. Arnson, Y.; Amital, H.; Agmon-Levin, N.; Alon, D.; Sánchez-Castañón, M.; López-Hoyos, M.; Matucci-Cerinic, M.; Szücs, G.; Shapira, Y.; Szekanecz, Z.; et al. Serum 25-OH vitamin D concentrations are linked with various clinical aspects in patients with systemic sclerosis: A retrospective cohort study and review of the literature. Autoimmun. Rev. 2011, 10, 490-494. [CrossRef]

65. Bettencourt, A.; Boleixa, D.; Reguengo, H.; Samões, R.; Santos, E.; Oliveira, J.C.; Silva, B.; Costa, P.P.; da Silva, A.M. Serum 25-hydroxyvitamin D levels in multiple sclerosis patients from the north of Portugal. J. Steroid Biochem. Mol. Biol. 2018, 180, 137-141. [CrossRef] [PubMed]

66. Martínez-Lapiscina, E.H.; Mahatanan, R.; Lee, C.H.; Charoenpong, P.; Hong, J.P. Associations of serum 25(OH) vitamin D levels with clinical and radiological outcomes in multiple sclerosis, a systematic review and meta-analysis. J. Neurol. Sci. 2020, 411, 116668. [CrossRef]

67. Amezcua, L.; Chung, R.H.; Conti, D.V.; Langer-Gould, A.M. Vitamin D levels in Hispanics with multiple sclerosis. J. Neurol. 2012, 259, 2565-2570. [CrossRef]

68. Skalli, A.; Ait Ben Haddou, E.H.; El Jaoudi, R.; Razine, R.; Mpandzou, G.A.; Tibar, H.; El Fahime, E.; Bouslam, N.; Alami, A.; Benomar, A.; et al. Association of vitamin D status with multiple sclerosis in a case-control study from Morocco. Rev. Neurol. 2018, 174, 150-156. [CrossRef]

69. Martinelli, V.; Dalla Costa, G.; Colombo, B.; Dalla Libera, D.; Rubinacci, A.; Filippi, M.; Furlan, R.; Comi, G. Vitamin D levels and risk of multiple sclerosis in patients with clinically isolated syndromes. Mult. Scler. 2014, 20, 147-155. [CrossRef]

70. Ueda, P.; Rafatnia, F.; Bäärnhielm, M.; Fröbom, R.; Korzunowicz, G.; Lönnerbro, R.; Hedström, A.K.; Eyles, D.; Olsson, T.; Alfredsson, L. Neonatal vitamin D status and risk of multiple sclerosis. Ann. Neurol. 2014, 76, 338-346. [CrossRef] [PubMed]

71. Ismailova, K.; Poudel, P.; Parlesak, A.; Frederiksen, P.; Heitmann, B.L. (Vitamin D in early life and later risk of multiple sclerosis-A systematic review, meta-analysis. PLoS ONE 2019, 14, e0221645. [CrossRef] [PubMed]

72. Abbatemarco, J.R.; Fox, R.J.; Li, H.; Ontaneda, D. Vitamin D and MRI measures in progressive multiple sclerosis. Mult. Scler. Relat. Disord. 2019, 35, 276-282. [CrossRef] [PubMed]

73. Mesliniene, S.; Ramrattan, L.; Giddings, S.; Sheikh-Ali, M. Role of vitamin D in the onset, progression, and severity of multiple sclerosis. Endocr. Pract. 2013, 19, 129-136. [CrossRef] [PubMed]

74. Duan, S.; Lv, Z.; Fan, X.; Wang, L.; Han, F.; Wang, H.; Bi, S. Vitamin D status and the risk of multiple sclerosis: A systematic review and meta-analysis. Neurosci. Lett. 2014, 570, 108-113. [CrossRef]

75. Pakpoor, J.; Ramagopalan, S. Evidence for an Association Between Vitamin D and Multiple Sclerosis. Curr. Top Behav. Neurosci. 2015, 26, 105-115.

76. Piędel, F.; Rocka, A.; Piwek, M.; Jasielski, P.P.; Petit, V.; Rejdak, K. Correlation between vitamin D and alterations in MRI among patients with multiple sclerosis. Ann. Agric. Environ. Med. 2021, 28, 372-377. [CrossRef]

77. Voo, V.; O'Brien, T.; Butzkueven, H.; Monif, M. The role of vitamin D and P2X7R in multiple sclerosis. J. Neuroimmunol. 2019, 330, 159-169. [CrossRef]

78. Lin, F.Y.; Lin, Y.F.; Lin, Y.S.; Yang, C.M.; Wang, C.C.; Hsiao, Y.H. Relative D3 vitamin deficiency and consequent cognitive impairment in an animal model of Alzheimer's disease: Potential involvement of collapsin response mediator protein-2. Neuropharmacology 2020, 164, 107910. [CrossRef]

79. Al-Amin, M.; Bradford, D.; Sullivan, R.; Kurniawan, N.D.; Moon, Y.; Han, S.H.; Zalesky, A.; Burne, T. Vitamin D deficiency is associated with reduced hippocampal volume and disrupted structural connectivity in patients with mild cognitive impairment. Hum Brain Mapp. 2019, 40, 394-406. [CrossRef]

80. Aguilar-Navarro, S.G.; Mimenza-Alvarado, A.J.; Jiménez-Castillo, G.A.; Bracho-Vela, L.A.; Yeverino-Castro, S.G.; Ávila-Funes, J.A. Association of vitamin D with mild cognitive impairment and Alzheimer's dementia in older Mexican adults. Rev. Investig. Clin. 2019, 71, 381-386. 
81. Mehri, N.; Haddadi, R.; Ganji, M.; Shahidi, S.; Soleimani Asl, S.; Taheri Azandariani, M.; Ranjbar, A. Effects of vitamin D in an animal model of Alzheimer's disease: Behavioral assessment with biochemical investigation of Hippocampus and serum. Metab. Brain Dis. 2020, 35, 263-274. [CrossRef]

82. Yang, K.; Chen, J.; Li, X.; Zhou, Y. Vitamin D concentration and risk of Alzheimer disease: A meta-analysis of prospective cohort studies. Medicine 2019, 98, e16804. [CrossRef] [PubMed]

83. Chai, B.; Gao, F.; Wu, R.; Dong, T.; Gu, C.; Lin, Q.; Zhang, Y. Vitamin D deficiency as a risk factor for dementia and Alzheimer's disease: An updated meta-analysis. BMC Neurol. 2019, 19, 284. [CrossRef] [PubMed]

84. Kalra, A.; Teixeira, A.L.; Diniz, B.S. Association of Vitamin D Levels with Incident All-Cause Dementia in Longitudinal Observational Studies: A Systematic Review and Meta-analysis. J. Prev. Alzheimers Dis. 2020, 7, 14-20.

85. Mavraki, E.; Ioannidis, P.; Tripsianis, G.; Gioka, T.; Kolousi, M.; Vadikolias, K. Vitamin D in mild cognitive impairment and Alzheimer's disease. A study in older Greek adults. Hippokratia 2020, 24, 120-126. [PubMed]

86. Wang, L.; Qiao, Y.; Zhang, H.; Zhang, Y.; Hua, J.; Jin, S.; Liu, G. Circulating Vitamin D Levels and Alzheimer's Disease: A Mendelian Randomization Study in the IGAP and UK Biobank. J. Alzheimers Dis. 2020, 73, 609-618. [CrossRef]

87. Sultan, S.; Taimuri, U.; Basnan, S.A.; Ai-Orabi, W.K.; Awadallah, A.; Almowald, F.; Hazazi, A. Low Vitamin D and Its Association with Cognitive Impairment and Dementia. J. Aging Res. 2020, 2020, 6097820. [CrossRef] [PubMed]

88. Yeşil, Y.; Kuyumcu, M.E.; Kara, Ö.; Halaçli, B.; Etgül, S.; Kizilarslanoğlu, M.C.; Yavuz, B.B.; Özcan, M.; Halil, M.G.; Sahin Cankurtaran, E.; et al. Vitamin D status and its association with gradual decline in cognitive function. Turk. J. Med. Sci. 2015, 45, 1051-1057. [CrossRef] [PubMed]

89. Shen, L.; Ji, H.F. Vitamin D deficiency is associated with increased risk of Alzheimer's disease and dementia: Evidence from meta-analysis. Nutr. J. 2015, 14, 76. [CrossRef] [PubMed]

90. Keeney, J.T.; Butterfield, D.A. Vitamin D deficiency and Alzheimer disease: Common links. Neurobiol. Dis. 2015, 84, 84-98. [CrossRef]

91. Goodwill, A.M.; Campbell, S.; Simpson, S., Jr.; Bisignano, M.; Chiang, C.; Dennerstein, L.; Szoeke, C. Vitamin D status is associated with executive function a decade later: Data from the Women's Healthy Ageing Project. Maturitas 2018, 107, 56-62. [CrossRef] [PubMed]

92. Nourhashemi, F.; Hooper, C.; Cantet, C.; Féart, C.; Gennero, I.; Payoux, P.; Salabert, A.S.; Guyonnet, S.; De Souto Barreto, P.; Vellas, B.; et al. Cross-sectional associations of plasma vitamin $\mathrm{D}$ with cerebral $\beta$-amyloid in older adults at risk of dementia. Alzheimers Res. Ther. 2018, 10, 43. [CrossRef] [PubMed]

93. Yamini, P.; Ray, R.S.; Chopra, K. Vitamin D3 attenuates cognitive deficits and neuroinflammatory responses in ICV-STZ induced sporadic Alzheimer's disease. Inflammopharmacology 2018, 26, 39-55. [CrossRef] [PubMed]

94. Moore, K.; Hughes, C.F.; Ward, M.; Hoey, L.; McNulty, H. Diet, nutrition and the ageing brain: Current evidence and new directions. Proc. Nutr. Soc. 2018, 77, 152-163. [CrossRef] [PubMed]

95. Berridge, M.J. Vitamin D deficiency accelerates ageing and age-related diseases: A novel hypothesis. J. Physiol. 2017, 595, 6825-6836. [CrossRef]

96. Annweiler, C.; Llewellyn, D.J.; \& Beauchet, O. Low serum vitamin D concentrations in Alzheimer's disease: A systematic review and meta-analysis. J. Alzheimer Dis. 2013, 33, 659-674. [CrossRef]

97. Morello, M.; Landel, V.; Lacassagne, E.; Baranger, K.; Annweiler, C.; Féron, F.; Millet, P. Vitamin D Improves Neurogenesis and Cognition in a Mouse Model of Alzheimer's Disease. Mol. Neurobiol. 2018, 55, 6463-6479. [CrossRef]

98. Littlejohns, T.J.; Henley, W.E.; Lang, I.A.; Annweiler, C.; Beauchet, O.; Chaves, P.H.; Fried, L.; Kestenbaum, B.R.; Kuller, L.H.; Langa, K.M.; et al. Vitamin D and the risk of dementia and Alzheimer disease. Neurology 2014, 83, 920-928. [CrossRef]

99. Licher, S.; de Bruijn, R.F.A.G.; Wolters, F.J.; Zillikens, M.C.; Ikram, M.A.; Ikram, M.K. Vitamin D and the risk of dementia: The Rotterdam study. J. Alzheimers Dis. 2017, 60, 989-997. [CrossRef]

100. Ouma, S.; Suenaga, M.; Bölükbaşı Hatip, F.F.; Hatip-Al-Khatib, I.; Tsuboi, Y.; Matsunaga, Y. Serum vitamin D in patients with mild cognitive impairment and Alzheimer's disease. Brain Behav. 2018, 8, e00936. [CrossRef]

101. Afzal, S.; Bojesen, S.E.; Nordestgaard, B.G. Reduced 25-hydroxyvitamin D and risk of Alzheimer's disease and vascular dementia. Alzheimers Dement. 2014, 10, 296-302. [CrossRef]

102. Ertilav, E.; Barcin, N.E.; Ozdem, S. Comparison of Serum Free and Bioavailable 25-Hydroxyvitamin D Levels in Alzheimer's Disease and Healthy Control Patients. Lab. Med. 2020, 52, 219-225. [CrossRef] [PubMed]

103. Balion, C.; Griffith, L.E.; Strifler, L.; Henderson, M.; Patterson, C.; Heckman, G.; Llewellyn, D.J.; Raina, P. Vitamin D, cognition, and dementia: A systematic review and meta-analysis. Neurology 2012, 79, 1397-1405. [CrossRef]

104. Ulstein, I.; Bøhmer, T. Normal Vitamin Levels and Nutritional Indices in Alzheimer's Disease Patients with Mild Cognitive Impairment or Dementia with Normal Body Mass Indexes. J. Alzheimers Dis. 2017, 55, 717-725. [CrossRef]

105. Olsson, E.; Byberg, L.; Karlström, B.; Cederholm, T.; Melhus, H.; Sjögren, P.; Kilander, L. Vitamin D is not associated with incident dementia or cognitive impairment: An 18-y follow-up study in community-living old men. Am. J. Clin. Nutr. 2017, 105, 936-943. [CrossRef] [PubMed]

106. Karakis, I.; Pase, M.P.; Beiser, A.; Booth, S.L.; Jacques, P.F.; Rogers, G.; DeCarli, C.; Vasan, R.S.; Wang, T.J.; Himali, J.J.; et al. Association of serum vitamin D with the risk of incident dementia and subclinical indices of brain aging: The Framingham Heart Study. J. Alzheimers Dis. 2016, 51, 451-461. [CrossRef] 
107. Duchaine, C.S.; Talbot, D.; Nafti, M.; Giguère, Y.; Dodin, S.; Tourigny, A. Vitamin D status, cognitive decline and incident dementia: The Canadian Study of Health and Aging. Can. J. Public Health 2020, 111, 312-321. [CrossRef] [PubMed]

108. Graf, C.E.; Rossi, C.; Giannelli, S.V.; Nobari, B.H.; Gold, G.; Herrmann, F.R.; Zekry, D. Vitamin D is not associated with cognitive status in a cohort of very old hospitalized patients. J. Alzheimers Dis. 2014, 42 (Suppl. 3), S53-S61. [CrossRef]

109. Jayedi, A.; Rashidy-Pour, A.; Shab-Bidar, S. Vitamin D status and risk of dementia and Alzheimer's disease: A meta-analysis of dose-response. Nutr. Neurosci. 2019, 22, 750-759. [CrossRef]

110. Limongi, F.; Noale, M.; Bianchetti, A.; Ferrara, N.; Padovani, A.; Scarpini, E.; Trabucchi, M.; Maggi, S.; MCI Working Group. The instruments used by the Italian centres for cognitive disorders and dementia to diagnose mild cognitive impairment (MCI). Aging Clin. Exp Res. 2019, 31, 101-107. [CrossRef]

111. Alongi, P.; Sardina, D.S.; Coppola, R.; Scalisi, S.; Puglisi, V.; Arnone, A.; Raimondo, G.D.; Munerati, E.; Alaimo, V.; Midiri, F.; et al. 18F-Florbetaben PET/CT to Assess Alzheimer's Disease: A new Analysis Method for Regional Amyloid Quantification. J. Neuroimaging 2019, 29, 383-393. [CrossRef] [PubMed]

112. Bonanni, L.; Cagnin, A.; Agosta, F.; Babiloni, C.; Borroni, B.; Bozzali, M.; Bruni, A.C.; Filippi, M.; Galimberti, D.; Monastero, R.; et al. The Italian dementia with Lewy bodies study group (DLB-SINdem): Toward a standardization of clinical procedures and multicenter cohort studies design. Neurol. Sci. 2017, 38, 83-91. [CrossRef] [PubMed]

113. Ciaccio, M.; Lo Sasso, B.; Scazzone, C.; Gambino, C.M.; Ciaccio, A.M.; Bivona, G.; Piccoli, T.; Giglio, R.V.; Agnello, L. COVID-19 and Alzheimer's Disease. Brain Sci. 2021, 11, 305. [CrossRef]

114. Annweiler, C.; Schott, A.M.; Berrut, G.; Chauviré, V.; Le Gall, D.; Inzitari, M.; Beauchet, O. Vitamin D and ageing: Neurological issues. Neuropsychobiology 2010, 62, 139-150. [CrossRef]

115. Evatt, M.L.; Delong, M.R.; Khazai, N.; Rosen, A.; Triche, S.; Tangpricha, V. Prevalence of vitamin d insufficiency in patients with Parkinson disease and Alzheimer disease. Arch. Neurol. 2008, 65, 1348-1352. [CrossRef]

116. Sato, Y.; Kikuyama, M.; Oizumi, K. High prevalence of vitamin D deficiency and reduced bone mass in Parkinson's disease. Neurology 1997, 49, 1273-1278, Retraction in Neurology 2020, 94, 804. [CrossRef] [PubMed]

117. Knekt, P.; Kilkkinen, A.; Rissanen, H.; Marniemi, J.; Sääksjärvi, K.; Heliövaara, M. Serum vitamin D and the risk of Parkinson disease. Arch. Neurol. 2010, 67, 808-811. [CrossRef]

118. Ding, H.; Dhima, K.; Lockhart, K.C.; Locascio, J.J.; Hoesing, A.N.; Duong, K.; Trisini-Lipsanopoulos, A.; Hayes, M.T.; Sohur, U.S.; Wills, A.M.; et al. Unrecognized vitamin D3 deficiency is common in Parkinson disease: Harvard Biomarker Study. Neurology 2013, 81, 1531-1537. [CrossRef]

119. Sleeman, I.; Aspray, T.; Lawson, R.; Coleman, S.; Duncan, G.; Khoo, T.K.; Schoenmakers, I.; Rochester, L.; Burn, D.; Yarnall, A. The Role of Vitamin D in Disease Progression in Early Parkinson's Disease. J. Parkinsons Dis. 2017, 7, 669-675. [CrossRef]

120. Luo, X.; Ou, R.; Dutta, R.; Tian, Y.; Xiong, H.; Shang, H. Association Between Serum Vitamin D Levels and Parkinson's Disease: A Systematic Review and Meta-Analysis. Front. Neurol. 2018, 9, 909. [CrossRef]

121. Zhou, Z.; Zhou, R.; Zhang, Z.; Li, K. The Association Between Vitamin D Status, Vitamin D Supplementation, Sunlight Exposure, and Parkinson's Disease: A Systematic Review and Meta-Analysis. Med. Sci. Monit. 2019, 25, 666-674. [CrossRef] [PubMed]

122. Lee, D.M.; Tajar, A.; O’Neill, T.W.; O'Connor, D.B.; Bartfai, G.; Boonen, S.; Bouillon, R.; Casanueva, F.F.; Finn, J.D.; Forti, G.; et al. Lower vitamin D levels are associated with depression among community-dwelling European men. J. Psychopharmacol. 2011, 25, 1320-1328. [CrossRef]

123. Kjærgaard, M.; Waterloo, K.; Wang, C.E.; Almås, B.; Figenschau, Y.; Hutchinson, M.S.; Svartberg, J.; Jorde, R. Effect of vitamin D supplement on depression scores in people with low levels of serum 25-hydroxyvitamin D: Nested case-control study and randomised clinical trial. Br. J. Psychiatry 2012, 201, 360-368. [CrossRef]

124. Milaneschi, Y.; Hoogendijk, W.; Lips, P.; Heijboer, A.C.; Schoevers, R.; van Hemert, A.M.; Beekman, A.T.; Smit, J.H.; Penninx, B.W. The association between low vitamin D and depressive disorders. Mol. Psychiatry 2014, 19, 444-451. [CrossRef] [PubMed]

125. Song, B.M.; Kim, H.C.; Rhee, Y.; Youm, Y.; Kim, C.O. Association between serum 25-hydroxyvitamin D concentrations and depressive symptoms in an older Korean population: A cross-sectional study. J. Affec. Disord. 2016, 189, 357-364. [CrossRef] [PubMed]

126. Sherchand, O.; Sapkota, N.; Chaudhari, R.K.; Khan, S.A.; Baranwal, J.K.; Pokhrel, T.; Das, B.; Lamsal, M. Association between vitamin D deficiency and depression in Nepalese population. Psychiatry Res. 2018, 267, 266-271. [CrossRef]

127. Vidgren, M.; Virtanen, J.K.; Tolmunen, T.; Nurmi, T.; Tuomainen, T.P.; Voutilainen, S.; Ruusunen, A. Serum Concentrations of 25-Hydroxyvitamin D and Depression in a General Middle-Aged to Elderly Population in Finland. J. Nutr. Health Aging 2018, 22, 159-164. [CrossRef]

128. Zhao, G.; Ford, E.S.; Li, C.; Balluz, L.S. No associations between serum concentrations of 25-hydroxyvitamin D and parathyroid hormone and depression among US adults. Br. J. Nutr. 2010, 104, 1696-1702. [CrossRef]

129. Kwasky, A.N.; Groh, C.J. Vitamin d, depression and coping self-efficacy in young women: Longitudinal study. Arch. Psychiatr. Nur. 2014, 28, 362-367. [CrossRef]

130. Can, M.S.; Baykan, H.; Baykan, O.; Erensoy, N.; Karlidere, T. Vitamin D levels and vitamin D receptor gene polymorphism in major depression. Psychiatr. Danub. 2017, 29, 179-185.

131. Bossola, M.; Ciciarelli, C.; Di Stasio, E.; Conte, G.L.; Vulpio, C.; Luciani, G.; Tazza, L. Correlates of symptoms of depression and anxiety in chronic hemodialysis patients. Gen. Hosp. Psychiatry 2010, 32, 125-131, Correction in Gen. Hosp. Psychiatry 2010, 32, 450. [CrossRef] 
132. Almeida, O.P.; Hankey, G.J.; Yeap, B.B.; Golledge, J.; Flicker, L. Vitamin D concentration and its association with past, current and future depression in older men: The health in men study. Maturitas 2015, 81, 36-41. [CrossRef]

133. Berg, A.O.; Melle, I.; Torjesen, P.A.; Lien, L.; Hauff, E.; Andreassen, O.A. A cross-sectional study of vitamin D deficiency among immigrants and Norwegians with psychosis compared to the general population. J. Clin. Psychiatry 2010, 71, 1598-1604. [CrossRef]

134. Crews, M.; Lally, J.; Gardner-Sood, P.; Howes, O.; Bonaccorso, S.; Smith, S.; Murray, R.M.; Di Forti, M.; Gaughran, F. Vitamin D deficiency in first episode psychosis: A case-control study. Schizophr. Res. 2013, 150, 533-537. [CrossRef] [PubMed]

135. Firth, J.; Carney, R.; Stubbs, B.; Teasdale, S.B.; Vancampfort, D.; Ward, P.B.; Berk, M.; Sarris, J. Nutritional Deficiencies and Clinical Correlates in First-Episode Psychosis: A Systematic Review and Meta-analysis. Schizophr. Bull. 2018, 44, 1275-1292. [CrossRef] [PubMed]

136. Norelli, L.J.; Coates, A.D.; Kovasznay, B.M. A comparison of 25-hydroxyvitamin D serum levels in acute and long-stay psychiatric inpatients: A preliminary investigation. $e$-SPEN 2010, 5, e187-e189. [CrossRef]

137. Zhu, J.L.; Luo, W.W.; Cheng, X.; Li, Y.; Zhang, Q.Z.; Peng, W.X. Vitamin D deficiency and Schizophrenia in Adults: A Systematic Review and Meta-analysis of Observational Studies. Psychiatry Res. 2020, 288, 112959. [CrossRef]

138. Yesil, H.; Sungur, U.; Akdeniz, S.; Gurer, G.; Yalcın, B.; Dundar, U. Association between serum vitamin D levels and neuropathic pain in rheumatoid arthritis patients: A cross-sectional study. Int. J. Rheum. Dis. 2018, 21, 431-439. [CrossRef]

139. Gopinath, K.; Danda, D. Supplementation of 1,25 dihydroxy vitamin D3 in patients with treatment naive early rheumatoid arthritis: A randomised controlled trial. Int. J. Rheum. Dis. 2011, 14, 332-339. [CrossRef]

140. Brink, M.; Johansson, L.; Nygren, E.; Ärlestig, L.; Hultdin, J.; Rantapää-Dahlqvist, S. Vitamin D in individuals before onset of rheumatoid arthritis-Relation to vitamin D binding protein and its associated genetic variants. BMC Rheumatol. 2018, 2, 26. [CrossRef]

141. Lima, G.L.; Paupitz, J.; Aikawa, N.E.; Takayama, L.; Bonfa, E.; Pereira, R.M. Vitamin D Supplementation in Adolescents and Young Adults with Juvenile Systemic Lupus Erythematosus for Improvement in Disease Activity and Fatigue Scores: A Randomized, Double-Blind, Placebo-Controlled Trial. Arthritis Care Res. 2016, 68, 91-98. [CrossRef]

142. Zheng, R.; Gonzalez, A.; Yue, J.; Wu, X.; Qiu, M.; Gui, L.; Zhu, S.; Huang, L. Efficacy and Safety of Vitamin D Supplementation in Patients with Systemic Lupus Erythematosus: A Meta-analysis of Randomized Controlled Trials. Am. J. Med. Sci. 2019, 358, 104-114. [CrossRef]

143. Doosti-Irani, A.; Tamtaji, O.R.; Mansournia, M.A.; Ghayour-Mobarhan, M.; Ferns, G.; Daneshvar Kakhaki, R.; Rezaei Shahmirzadi, A.; Asemi, Z. The effects of vitamin D supplementation on expanded disability status scale in people with multiple sclerosis: A critical, systematic review and metaanalysis of randomized controlled trials. Clin. Neurol. Neurosurg. 2019, 187, 105564. [CrossRef] [PubMed]

144. Zheng, C.; He, L.; Liu, L.; Zhu, J.; Jin, T. The efficacy of vitamin D in multiple sclerosis: A meta-analysis. Mult. Scler. Relat. Disord. 2018, 23, 56-61. [CrossRef] [PubMed]

145. Quirant-Sánchez, B.; Mansilla, M.J.; Navarro-Barriuso, J.; Presas-Rodríguez, S.; Teniente-Serra, A.; Fondelli, F.; Ramo-Tello, C.; Martínez-Cáceres, E. Combined Therapy of Vitamin D3-Tolerogenic Dendritic Cells and Interferon- $\beta$ in a Preclinical Model of Multiple Sclerosis. Biomedicines 2021, 9, 1758. [CrossRef]

146. Rossom, R.C.; Espeland, M.A.; Manson, J.E.; Dysken, M.W.; Johnson, K.C.; Lane, D.S.; LeBlanc, E.S.; Lederle, F.A.; Masaki, K.H.; Margolis, K.L. Calcium and vitamin D supplementation and cognitive impairment in the women's health initiative. J. Am. Geriatr. Soc. 2012, 60, 2197-2205. [CrossRef]

147. Annweiler, C.; Herrmann, F.R.; Fantino, B.; Brugg, B.; Beauchet, O. Effectiveness of the combination of memantine plus vitamin D on cognition in patients with Alzheimer disease: A pre-post pilot study. Cogn. Behav. Neurol. 2012, 25, 121-127. [CrossRef]

148. Rutjes, A.W.; Denton, D.A.; Di Nisio, M.; Chong, L.Y.; Abraham, R.P.; Al-Assaf, A.S.; Anderson, J.L.; Malik, M.A.; Vernooij, R.W.; Martínez, G.; et al. Vitamin and mineral supplementation for maintaining cognitive function in cognitively healthy people in mid and late life. Cochrane Database Syst. Rev. 2018, 12, CD011906. [CrossRef]

149. Han, J.H.; Ginde, A.A.; Brown, S.M.; Baughman, A.; Collar, E.M.; Ely, E.W.; Gong, M.N.; Hope, A.A.; Hou, P.C.; Hough, C.L.; et al. Effect of Early High-Dose Vitamin D3 Repletion on Cognitive Outcomes in Critically Ill Adults. Chest 2021, 160, 909-918. [CrossRef]

150. Hiller, A.L.; Murchison, C.F.; Lobb, B.M.; O'Connor, S.; O'Connor, M.; Quinn, J.F. A randomized, controlled pilot study of the effects of vitamin D supplementation on balance in Parkinson's disease: Does age matter? PLoS ONE 2018, 13, e0203637. [CrossRef] [PubMed]

151. Muir, S.W.; Montero-Odasso, M. Effect of vitamin D supplementation on muscle strength, gait and balance in older adults: A systematic review and meta-analysis. J. Am. Geriatr. Soc. 2011, 59, 2291-2300. [CrossRef] [PubMed]

152. Suzuki, M.; Yoshioka, M.; Hashimoto, M.; Murakami, M.; Noya, M.; Takahashi, D.; Urashima, M. Randomized, double-blind, placebo-controlled trial of vitamin D supplementation in Parkinson disease. Am. J. Clin. Nutr. 2013, 97, 1004-1013. [CrossRef] [PubMed]

153. Al-Daghri, N.M.; Mohammed, A.K.; Bukhari, I.; Rikli, M.; Abdi, S.; Ansari, M.; Sabico, S.; Hussain, S.D.; Alenad, A.; Al-Saleh Y.; et al. Efficacy of vitamin D supplementation according to vitamin D-binding protein polymorphisms. Nutrition 2019, 63-64, 148-154. [CrossRef] [PubMed] 